\title{
Can Factor Timing Explain Hedge Fund Alpha?
}

\author{
Hyuna Park \\ Minnesota State University, Mankato*
}

First Draft: June 12, 2009

This Version: December 23, 2010

\begin{abstract}
Hedge funds are in a better position than mutual funds in timing systematic risk factors because they are less regulated and thus have more freedom to use leverage and short sales. To examine whether factor timing is a source of hedge fund alpha, this paper decomposes excess return generated by hedge funds during 1994 - 2008 into security selection, factor timing, and risk premium using the new measure of performance developed by Lo (2008). I find that security selection on average explains most of the excess return generated by hedge funds, and the contributions of factor timing and risk premium are trivial. In the U.S. equity market, hedge funds on average show negative timing ability especially in recent years that include the financial crisis period of 2007-08.
\end{abstract}

Key words: factor timing, security selection, hedge fund alpha, return decomposition JEL classification: G01, G11, G17, G23

\footnotetext{
* Hyuna Park is assistant professor of finance at the College of Business, Minnesota State University, Mankato, 150 Morris Hall, Mankato, MN 56001, phone: (507) 389-5406, e-mail: hyuna.park@mnsu.edu. I am grateful for comments from Nicole Boyson, Christopher Schwarz, and the seminar participants at Minnesota State University, Mankato. I am responsible for any error.
} 


\title{
Can Factor Timing Explain Hedge Fund Alpha?
}

\begin{abstract}
Hedge funds are in a better position than mutual funds in timing systematic risk factors because they are less regulated and thus have more freedom to use leverage and short sales. To examine whether factor timing is a source of hedge fund alpha, this paper decomposes excess return generated by hedge funds during 1994 - 2008 into security selection, factor timing, and risk premium using the new measure of performance developed by Lo (2008). I find that security selection on average explains most of the excess return generated by hedge funds, and the contributions of factor timing and risk premium are trivial. In the U.S. equity market, hedge funds on average show negative timing ability especially in recent years that include the financial crisis period of 2007-08.

Key words: factor timing, security selection, hedge fund alpha, return decomposition JEL classification: G01, G11, G17, G23
\end{abstract}




\section{Introduction}

Can professional money managers deliver positive abnormal returns consistently? Previous research finds that such "hot hands” are rare among mutual funds, and estimated alphas for the majority of equity mutual funds are negative (Pastor and Stambaugh (2002)). However, there is growing evidence that hot hands do exist among hedge fund managers, and their performance cannot be explained by luck (Kosowski, Naik, and Teo (2007), Fung, Hsieh, Naik, and Ramadorai (2008), and Jagannathan, Malakhov, and Novikov (2010)). Previous research also finds that mutual funds mimicking hedge fund strategies outperform traditional mutual funds but underperform hedge funds (Agarwal, Boyson, and Naik (2009) and Nohel, Wang, and Zheng (2010).

Why do we observe a positive alpha more often in hedge funds than in mutual funds even after adjusting for high fees hedge fund managers charge for their service? ${ }^{1}$ Is it because the incentive fee of hedge funds can attract managers with security selection skills, or because hedge funds are better positioned than mutual funds for timing systematic risk factors due to looser regulation? Hedge funds can change their loadings on systematic risk factors more freely than mutual funds because they are less regulated in terms of using leverage and short sales. ${ }^{2}$ That is, hedge funds are in a better position than mutual funds in generating alpha using factor timing. Can factor timing explain hedge fund alpha? The main objective of this paper is to answer this question. To my knowledge, this is the first empirical study that decomposes excess return on hedge funds into factor timing, security selection, and risk premium.

\footnotetext{
${ }^{1}$ A typical hedge fund charges a 10-20\% incentive fee on top of a 1-2\% management fee, while most mutual funds do not charge an incentive fee.

${ }^{2}$ Mutual funds are required to register with the Securities and Exchange Commission (SEC), but most hedge funds are exempt from registration by either Section 3(c)(1) or Section 3(c)(7) of the Investment Company Act of 1940. See Liang and Park (2010b) for details on the hedge fund exemption conditions. See Almazan, et al. (2004) for regulation on mutual funds.
} 
To measure the factor timing component of hedge fund alpha, I use the new measure of performance developed by Lo (2008) who shows that the expected return on a portfolio can be decomposed into three components: security selection, factor timing, and risk premium. Factor timing ability is measured by the covariance between beta and factor risk premium. For example, if a fund has a high beta when the U.S. market return is high (34.11\% in 1995, for instance) and reduces beta successfully before a market crash (-38.49\% in 2008, for example), the covariance between the fund beta and market risk premium is positive and the fund has a timing ability in the US equity market. ${ }^{3}$ In addition to the US equity market factor, this paper tests emerging market factor and all other systematic risk factors included in the seven-factor model of Fung and Hsieh (2004).

To test factor timing ability, this paper uses monthly return observations on 6114 funds in Tremont Advisory Shareholders Service (TASS) database during 1994-2008. TASS is the most widely utilized hedge fund data in the literature. Daily return data are not available for individual hedge funds, but the return decomposition methodology used in this paper can be applied most accurately when return observations are made more frequently than investment decisions. Therefore, I take two measures to address the sampling interval issue. First, I separate illiquid-style hedge funds from liquid ones using the method developed by Getmansky, Lo, and Makarov (2004) as infrequent return observations are less problematic when decomposing returns on illiquid style hedge funds. Second, I use daily return observations on twelve HFRX indices during April 2003 - March 2010 as a robustness check. ${ }^{4}$

\footnotetext{
${ }^{3}$ See section 3.2 for details on how to measure factor timing ability.

${ }^{4}$ Most hedge fund indices provide monthly returns only, but HFR (Hedge Fund Research) started providing daily return recently. Hedge fund indices most widely used in previous research are HFR indices, Dow Jones Credit Suisse Hedge Fund Indices, and CISDM (Center for International Securities and Derivatives Markets) hedge fund indices.
} 
I find that hedge funds on average do not show timing ability in the US equity market despite their advantage over registered investment companies such as mutual funds in terms of using leverage and short sales. Especially, the individual fund level test using illiquid-style hedge funds in TASS shows that the covariance between the U.S. equity market beta and risk premium is negative and significant at the 1 percent level. Figure 1 illustrates the negative timing ability of hedge funds in the US equity market. During the financial crisis of 2007-08, the excess return on S\&P500 index dropped sharply (from $0.31 \%$ to $-1.09 \%$ per month), but hedge funds on average increased their exposures to the US equity market. This pattern is observed at both the portfolio level (Figure 1a) and the individual fund level (Figure 1b) tests. Figure 1c shows that long-short equity hedge funds that trade liquid assets in the US equity market also show negative timing ability on average during the recent financial crisis. Daily returns on HFRX indices also show a similar pattern. For example, HFRXGL is an index designed to represent the overall composition of the hedge fund universe. As shown in Figure 2, the US equity market beta of HFRXGL index and market risk premium move to the opposite direction during the recent financial crisis.

Return decomposition analyses also confirm the negative factor timing of hedge funds. I find that factor timing on average did not increase excess return on illiquid-style hedge funds. In fact, security selection explains more than $100 \%$ of the excess return, and the proportion explained by factor timing is negative. That is, in case of illiquid-style hedge funds, factor timing reduced excess return generated by security selection. In liquid-style hedge funds, factor timing contributes to generating excess return but its contribution is much smaller than that of security selection. For example, among the excess return of $0.64 \%$ per month delivered by the equally weighted portfolio of 2924 liquid-style hedge funds during 1994-2008, security selection generated $0.50 \%$, factor timing generated $0.11 \%$, and the remaining $0.03 \%$ is the risk premium. 
Overall these results show that security selection, not factor timing, is the main source of hedge fund alphas. The existence of "hot hands" in hedge funds is not because of loose regulation that enhances factor timing potential. The main reason is mangers with security selection skills attracted to the hedge fund industry that has incentive fees. The remainder of this paper is organized as follows. I review the literature in Section 2. Section 3 describes the data and return decomposition methodology. Section 4 discusses the results, and Section 5 concludes.

\section{Literature Review}

The standard approach to evaluate fund performance, dating back to Jensen (1968), is to regress fund returns on systematic risk factors. Fung and Hsieh (2004) identify seven assetbased style factors to explain the variations in hedge fund returns. Fung, Hsieh, Naik, and Ramadorai (2008) use these factors to identify funds-of-funds capable of delivering alpha. Jagannathan et. al. (2010) use Fung and Hsieh’s factors to estimate hedge fund alphas and find significant performance persistence among superior funds.

When applying these factor models, returns are regarded as a random variable but the beta coefficients are usually assumed to be constant. Bollen and Whaley (2009) point out that the estimated alpha will be unreliable and shed no light on the skill of the fund manager if coefficients are assumed to be constant when they are in fact time-varying. Using an optimal change point regression model, they find that approximately $50 \%$ of hedge funds feature a statistically significant shift in risk exposures during 1994-2005.

However, previous research did not analyze whether the shift in risk exposures of hedge funds increased their performance or not. If they could successfully time the systematic risk factors, the shift in risk exposures of the funds would have increased their alphas. Lo (2008) 
develops a theoretical framework for testing the contribution of factor timing to performance. In contrast to much of the investment literature that focus on the randomness of returns and regards portfolio weights as fixed parameters, Lo regards both returns and portfolio weights as random variables and analyze the stochastic relation between weights and returns. His view is consistent with the practice of real-world investing because investors are willing to pay high fees to hedge funds mainly because of the manager's choice of portfolio weights.

Under the assumption that asset returns satisfy a liner factor model, Lo shows that the expected return of any portfolio can be decomposed into security selection, factor timing, and risk premium, and factor timing is measured by the covariance between factor loading and factor risk premium. This paper is the first empirical test of this theoretical model using hedge fund data.

Previous research tests the timing ability of hedge funds using the market timing models of Treynor and Mazuy (here after TM, 1966) and Henriksson and Merton (hereafter HM, 1981). For example, Fung, Xu, and Yau (2002) use the capital asset pricing model (CAPM) and the HM model to examine whether 311 hedge funds from Managed Accounts Reports (MAR) database can time global equity markets during 1994-2000. They find evidence of negative market timing ability especially in the funds targeting U.S. and European markets.

Chen (2007) extends TM (1966) and HM (1981) to analyze the timing ability of hedge funds in their focus markets, which are defined as the market where the funds trade most actively. Using 1,471 funds from TASS database during 1994-2002, he finds that a few categories such as global macro and managed futures can time the bond and currency markets, but timing ability is sparse in the equity market. Chen and Liang (2007) examine a sample of 221 self-described market timing hedge funds. They find timing ability of those funds in the U.S. equity market 
during 1994-2005 at both the aggregate and fund levels. While the TM and HM models used in previous research are silent about what proportion of alpha is attributable to market timing, Lo's methodology used in this paper can measure the amount of excess return generated by timing, selection, and risk premium.

Another related literature is on market efficiency and predictability of asset returns. If capital markets are efficient, prices reflect information to the point where marginal benefits of acting on the information do not exceed the marginal costs (Fama (1970 and 1991) and Jensen (1978)). In competitive markets with low trading costs such as the U.S. equity market, prices will reflect all available information, returns will be unpredictable, and thus market timing will not be observed.

Attempts to predict stock returns, dating back to Dow (1920), have a long history in finance, and the most prominent predictor variables explored in the literature are dividend yield, the earnings price ratio, volatility, consumption, equity issuing activity, and various interest rates and spreads. Welch and Goyal (2008) comprehensively reexamine the equity premium prediction models and conclude that these models would not have helped investors profitably time the market. Previous research also finds challenges in timing the bond market; Duffee (2002) and Diebold and Li (2006) examine the existing yield curve models out-of-sample and conclude that these models forecast poorly. This implies that even sophisticated investors such as hedge funds would find it difficult to time securities markets despite their advantage over other investment companies due to less regulatory oversight.

\section{Data and Methodology}

\subsection{Data and Summary Statistics}

Net-of-fee monthly returns and other characteristics on individual hedge funds are obtained 
from TASS during the sample period between January 1994 and December 2008. The fund characteristics provided by TASS includes investment styles, fee structure, high-water marks, minimum investment, subscription and redemption information, lockup provisions, and so on.

To reduce survivorship bias, I include both live and defunct funds in the analysis. ${ }^{5}$ As in previous research, I delete those funds that report returns in foreign currency (not in US dollar), have quarterly (not monthly) returns, or use gross return (not net-of-fee returns) from the original TASS database. Funds with less than 24 months of return history are not included. After these requirements, there remain 6114 funds in the sample (4246 hedge funds, 476 commodity trading advisors (CTAs), and 1392 funds-of-funds (FOFs)), and Panel A of Table 1 shows the summary statistics of these funds. ${ }^{6}$

As shown in the table, hedge fund alpha is positive and significant during 1994-2008. For example, the average alpha of the 4246 hedge funds is 0.43 percent per month, and it is significant at the 1 percent level. To adjust for backfill bias, I delete the first two years of return history from all funds before estimating alpha and find that alpha is still positive ( 0.34 percent per month) and significant at 1 percent level.

I test the factor timing and return decomposition analyses at both a portfolio level and an individual fund level. In the portfolio level test, I construct an equally-weighted portfolio of all funds in each investment style. All the 6114 funds in Table 1 are analyzed in the portfolio-level test. In the individual fund-level test, 906 funds that have 8 years or longer return history are analyzed. A long return history is needed for the fund-level test in order to estimate the covariance between beta and risk premium for each fund. That is, in order to be included in the

\footnotetext{
${ }^{5}$ For more details on biases in hedge fund databases and measures to mitigate them, see Fung and Hsieh (2000 and 2002). For reasons why hedge funds drop out of the live fund database and move to the defunct fund database, see Liang and Park (2010a).

${ }^{6}$ Liang (2004) shows that hedge funds are different from CTAs and FOFs in terms of performance, risk, attrition, and correlation structures with major market indices.
} 
fund-level test, a fund should have 24 or more monthly return data in each of the four or more sub-periods. ${ }^{7}$ Among the seven sub-periods during the fifteen years (1994-2008), the last subperiod (2006-2008) has three years and the others have two years.

As explained in the introduction, the return decomposition method used in this paper provides more accurate results when return observations are made more frequently than or at least as frequently as portfolio decisions. As monthly is the most frequent return observation interval available for hedge funds, it is important to measure the illiquidity of a hedge fund in order to find what investment styles provide more accurate results than others.

To measure illiquidity, I use a methodology developed by Getmansky, Lo, and Makarov (hereafter GLM, 2004) as follows. GLM (2004) suggests a measure of asset illiquidity by distinguishing between a fund's reported returns and economic returns. The idea is that the reported returns of illiquid portfolios only partially reflect the true economic returns contemporaneously but economic returns are incorporated to reported returns eventually. That is, the reported return in period $t\left(R_{t}^{0}\right)$ satisfies the following equations:

$$
\begin{aligned}
& R_{t}^{0}=\theta_{0} R_{t}+\theta_{1} R_{t-1}+\theta_{2} R_{t-2}+\cdots+\theta_{k} R_{t-k} \\
& 0 \leq \theta_{i} \leq 1 \text { for all } i=0,1,2, \cdots k, \text { and } \\
& \theta_{0}+\theta_{1}+\theta_{2}+\cdots+\theta_{k}=1
\end{aligned}
$$

where $R_{t}$ is the fund's true economic return in period $t$.

As in GLM (2004), I assume that demeaned economic returns are mean-zero, normal random variables, and use the previous sixty-month return history of a fund to estimate the parameters in Equation (1) by maximum likelihood estimation. $\theta_{0}$ represents the fraction of a fund's economic

\footnotetext{
${ }^{7}$ Section 4.1.2 discusses how to address the survivorship bias issue that is caused by the long return history requirement in the individual fund level test.
} 
return that is simultaneously incorporated in its reported return. Hence low $\theta_{0}$ means a more illiquid portfolio. Therefore, I call $\phi=1-\theta_{0}$ the GLM (2004) measure of asset illiquidity.

As shown in Panel A of Table 1, the average $\phi$ of all funds in the sample is 0.30 , which means $70 \%$ of a fund's economic return is simultaneously incorporated in its reported return on average. The investment styles that have illiquidity $(\phi)$ higher than the average are convertible arbitrage, event driven, emerging markets, and fixed income arbitrage. Therefore, these four styles are classified as illiquid investment styles. As the return decomposition analyses using monthly returns on liquid-style hedge funds have limitations, I also use daily returns on HFRX Indices during the period between April 1, 2003 and March 31, 2010 as a robustness check. Panel B of Table 1 shows the summary statistics of the indices.

\subsection{Return Decomposition Methodology}

I assume that the excess return of asset $\mathrm{i}\left(\mathrm{R}_{i t}\right)$ satisfies a linear $\mathrm{K}$-factor model:

$$
R_{i t}=\alpha_{i}+\sum_{j=1}^{K} \beta_{i j} F_{j t}+\varepsilon_{i t}, \quad E\left(\varepsilon_{i t} \mid F_{1 t, \cdots, F_{K t}}\right)=0
$$

Fund $\mathrm{P}$ invests in $\mathrm{n}$ assets with weights $\omega_{i t}, i=1, \ldots, \mathrm{n}$, and $\mathrm{R}_{\mathrm{pt}}$ denotes the fund's excess return during the period between $t-1$ and $t$ :

$$
\begin{aligned}
R_{P t} & =\sum_{i=1}^{n} \omega_{i t} R_{i t} \\
& =\sum_{i=1}^{n} \omega_{i t} \alpha_{i}+\sum_{j=1}^{K} \beta_{p j, t} F_{j t}+\varepsilon_{p t} \\
& \text { where } \beta_{p j, t}=\sum_{i=1}^{n} \omega_{i t} \beta_{i j} \text { and } \varepsilon_{p t}=\sum_{i=1}^{n} \omega_{i t} \varepsilon_{i t}
\end{aligned}
$$


Under these conditions, the expected excess return on Fund P can be decomposed into three components:

$$
\begin{aligned}
& E\left(R_{P t}\right)=\sum_{i=1}^{n} \alpha_{i} E\left(\omega_{i t}\right)+\sum_{j=1}^{K} \operatorname{Cov}\left[\beta_{p j, t}, F_{j t}\right]+\sum_{j=1}^{K} E\left(\beta_{p j, t}\right) E\left(F_{j t}\right) \\
& =\text { security selection }+ \text { factor timing }+ \text { risk premium } \\
& \text { where } \operatorname{Cov}\left[\beta_{p j, t}, F_{j t}\right]=\sum_{i=1}^{n} \beta_{i j} \operatorname{Cov}\left[\omega_{i t}, F_{j t}\right] \quad E\left(\beta_{p j, t}\right)=\sum_{i=1}^{n} \beta_{i j} E\left(\omega_{i t}\right), j=1, \cdots, K
\end{aligned}
$$

That is, the excess return attributable to factor timing is computed by adding all covariance between each factor and the factor loading. In the empirical test of this model, I use the following eight risk factors; i) the excess return on the S\&P 500 index (MFA), ii) the excess return on MSCI emerging market index (MSCI), iii) the size factor (SMB) as in Fama and French (1993), iv) the monthly change in the 10-year treasury constant maturity yield (CYD), v) the change in the credit spread of the Moody's Baa bond over the 10-year treasury bond (CSF), vi, vii, and viii)) the excess returns on portfolios of look back straddle options on currencies, commodities, and bonds (TFFX, TFCOM, TFBD) as in Fung and Hsieh (2001). ${ }^{8}$

I divide the fifteen-year sample period (1994 - 2008) into seven sub-periods. The first six sub-periods have two years and the last one has three years. First, I estimate the eight-factor model for each sub-period. Then I use the parameter estimates from the seven sub-periods in order to estimate covariance between factor loading and factor risk premium for each factor.

When testing daily returns on HFRX indices, I use a five-factor model because daily returns on the three trend-following factors are not available. I estimate the model for each of the twenty-eight quarters in the sample period (April 2003 - March 2010) and use the quarterly

\footnotetext{
${ }^{8}$ The size factor was obtained from http://mba.tuck.dartmouth.edu/pages/faculty/ken.french/data_library.html, The trend-following factors were downloaded from http://faculty.fuqua.duke.edu/ dah7/HFRFData.htm. I thank Kenneth French and David Hsieh for making the risk factor data available for download from their websites.
} 
parameter estimates to find covariance between factor loading and factor risk premium. As daily return on MSCI emerging market index is available from May 30, 2006, I estimate a four-factor model instead of a five-factor model during the thirteen quarters between April 1, 2003 and June 30, 2006. The alpha presented as summary statistics in Panel B of Table 1 is from a single period between May 30, 2006 and March 31, 2010 and it is based on the five-factor model. As this alpha estimation period is mostly during the financial crisis, ten out of the twelve indices have a negative alpha and five of them are significantly different from zero.

\section{Empirical Results}

\subsection{Factor Timing Ability of Hedge Funds}

\subsubsection{Portfolio-level test}

Table 2 shows the time-series variation in risk premium for each of the eight risk factors. Note that all risk factors show a high variability over time. For example, the average risk premium for the trend-following factor for currencies was as high as 4.90\% per month (2006-08) and it was as low as $-2.78 \%$ per month (1994-95).

As risk premium changed over time, so did the exposures of hedge funds to the risk factors. Table 3 shows how hedge fund beta for each risk factor changed over time. The reported numbers are the alpha, beta, and adjusted $\mathrm{R}^{2}$ of the eight-factor model applied to the equally weighted portfolio of 4246 hedge funds. Note that hedge funds are indeed "hedged" in the US equity market, so estimated factor loadings are not high (between -0.08 and 0.22 ) but they vary over time. If factor loading in Table 3 and factor risk premium in Table 2 have a positive covariance, hedge funds on average have factor timing ability. 
Table 4 presents the covariance between factor loading and risk premium for the equally weighted portfolio of funds in each investment style. Correlation coefficients are presented in parentheses. Note that among the 120 covariance estimates (15 investment style groups * 8 factors) only three are positive and significant. This means hedge funds, CTAs, and FOFs do not show timing ability in most of the eight risk factors on average. The three exceptions are for global macro funds in the US equity market, equity market neutral funds in the credit market, and dedicated short biased funds in the currency market (correlation coefficients of 0.81, 0.89, and 0.77 respectively). Among the 120 covariance estimates, 59 are negative and seven are significant. Note that all the 15 covariance estimates are negative and four of them are significant for the yield change factor (CYD). This means, it was especially difficult for hedge funds, CTAs, and FOFs to predict the change in interest rates during 1994-2008. This result is consistent with Duffee (2002) and Diebold and Li (2006) who find that existing interest rate forecasting models predict poorly.

\subsubsection{Fund-level test}

After finding mostly negative or insignificant factor timing in the portfolio-level test, I move on to the individual fund-level test and present the results in Table 5. In each of the seven subperiods, the eight-factor model is estimated for each fund in TASS and the time series of coefficient estimates from the seven regressions are used to estimate the covariance between beta and risk premium for each fund and for each factor. As explained in Section 3.1, 1357 funds that have eight years or longer return history are included in the fund-level test.

Table 5 shows the cross-sectional average values of the covariance in each investment style, and a $t$-test is used to evaluate the statistical significance of factor timing at the individual fund 
level. Note that the fund-level test should be interpreted with caution because survivorship bias may lead to finding positive factor timing ability spuriously as 8 years or longer return history is required. As funds with timing ability are more likely to survive than funds that lack the ability, the survivorship bias works for finding positive timing ability. Therefore, if we still find negative timing ability under the influence of the bias in the fund-level test, the result will not undermine but strengthen the evidence of negative timing found previously in the portfolio-level test.

The 906 Hedge funds analyzed in the fund-level test show a negative and significant timing ability on average in four of the eight systematic risk factors: the size factor (SMB), the yield change factor (CYD), and the trend-following factors in the bond market (TFBD) and in the currency market (TFFX). In illiquid-style hedge funds where this methodology can be applied more accurately, I also find negative and significant timing ability in the US equity market. This means an average hedge fund lacks the ability to time these risk factors.

Note that there are more positive and significant covariance estimates in Table 5 than in Table 4 (31 vs. 3). For example, hedge funds, CTAs, and FOFs all show positive and significant timing ability in the credit spread factor (CSF) at the fund-level test, but this may be caused by the survivorship bias because none shows such ability in the portfolio-level test. Three out of the 120 covariance estimates are positive and significant at the fund-level test as well as the portfolio-level test: global macro funds in the US equity market, equity market neutral funds in the credit market, and dedicated short biased funds in the currency market. However, the sample interval issue (monthly vs. daily) becomes critical for the funds in these three style categories because they invest in liquid assets. Therefore, I present a robustness test using daily returns on hedge fund indices in the next subsection. 


\subsubsection{Factor timing test using daily returns on HFRX indices}

Table 6 shows the daily index-level test. Among the sixty correlation coefficients (12 indices

* 5 factors), thirty are negative and nine of the thirty are significant. Positive and significant estimates are only two: equity market neutral index in the size factor and equal weighted index in the yield change factor. That is, the hedge funds included in HFRX indices could not time the equity and credit markets during $2003-2010$.

Note that among the three liquid-style hedge funds that show positive and significant timing ability when monthly data is used, two of them lose the ability when daily index data is in use: macro index in the US equity market (positive correlation but not significant) and equity market neutral index in the credit market (negative correlation). The third style (dedicated short biased funds) cannot be tested because daily index return is not available for this investment style.

\subsection{Decomposition of Excess Return}

The results presented so far evaluate whether hedge funds have timing ability for each risk factor. The remaining issue is whether factor timing collectively contributes to generating alpha. Table 7 shows the return decomposition result at the portfolio level. Among the excess return generated by the equally weighted portfolio of illiquid-style hedge funds during 1994-2008 (0.42\% per month), more than $100 \%$ is generated by security selection $(0.52 \%$ per month) and the contributions of factor timing and risk premium are negative $(-0.07 \%$ and $-0.04 \%$ per month, respectively). That is, factor timing did not increase but decreased the excess return in case of illiquid-style hedge funds. In liquid-style hedge funds, factor timing contributed to generating excess return but the contribution is much smaller than security selection $(0.11$ vs. $0.50 \%$ per 
month). That means, hedge fund alpha is attributable mainly to security selection, not to factor timing.

The fund-level test in Table 8 shows similar results. For example, the cross-sectional average values of excess return generated by security selection, factor timing, and risk premium in all the 1357 funds are $0.47 \%, 0.05 \%$, and $0.05 \%$ per month. The proportion of excess return explained by security selection is much higher than the corresponding value for factor timing ( $83.18 \%$ vs. 8.44\%). That is, the main source of hedge fund alpha is not market timing but finding mispriced assets.

Return decomposition analysis in Table 9 also shows poor timing ability of HFRX indices. 7 out of 12 indices have a negative excess return attributable to factor timing. This means factor timing reduced excess returns on these indices. For example, hedge funds in the event driven index earned 2.18\% per year as risk premium, 1.25\% per year from security selection, but lost 0.99\% per year due to negative factor timing.

Overall this paper finds that hedge funds on average do not show timing ability and thus security selection, not factor timing, is the main source of hedge fund alpha. This finding is consistent with Fung, Xu, and Yau (2002) who show that hedge funds on average have negative timing ability in the U.S. and European equity market. I interpret the lack of timing ability of hedge funds using the efficient market theory of Fama (1970 and 1991). In an efficient capital market, prices reflect all available information and professional money managers cannot time the market. As the U.S. equity market is arguably the most efficient capital market among existing ones, it is the least likely place where hedge fund managers show timing ability. This finding is also consistent with Welch and Goyal (2008) who comprehensively reexamine the performance 
of equity premium prediction models. They find that these models are unstable and would not have helped an investor to profitably time the market.

\section{Conclusion}

This paper tests factor timing ability of hedge funds, which can use leverage and short sales more freely and hence are in a better position to time securities markets than mutual funds. However, if financial markets are efficient, these advantages would not allow hedge funds to time the markets successfully. Using time series of risk premium and factor loadings estimated at both a portfolio level and a fund level, I find that hedge funds on average could not time the market during 1994-2008.

By applying the new measure of performance developed in Lo (2008), I find that most of the excess return generated by hedge funds during 1994-2008 is attributable to security selection. The proportions of the excess return explained by factor timing and risk premium are smaller than that of security selection (8.80\% and $0.88 \%$ vs. $90.32 \%)$. To my knowledge, this is the first empirical study that decomposes excess return on hedge funds into security selection, factor timing, and risk premium.

To confirm the findings based on monthly return data, I use daily returns on HFRX indices and find similar results. The main source of excess return on hedge fund indices is not factor timing but security selection. 


\section{References}

Agarwal, V., Boyson, N., and Naik, N., 2009, Hedge Funds for Retail Investors? An

Examination of Hedged Mutual Funds, Journal of Financial and Quantitative Analysis 44, 273305

Almazan, A., Brown, K., Carlson, M., and Chapman, D., 2004, Why Constrain Your Mutual Fund Manager? Journal of Financial Economics 73, 289-321

Bollen, N.P. and Whaley, R.E., 2009, Hedge fund risk dynamics: Implications for performance appraisal, Journal of Finance 64, 987-1037

Chen, Y., 2007, Timing Ability in the Focus Market of Hedge Funds, Journal of Investment Management 5, 66-98

Chen, Y. and Liang, B., 2007, Do Market Timing Hedge Funds Time the Market?, Journal of Financial and Quantitative Analysis 42(4), 827-856

Diebold, F. and Li, C., 2006, Forecasting the Term Structure of Government Bond Yield, Journal of Econometrics 130, 337-364

Dow, C. H., 1920, Scientific Stock Speculation, The Magazine of Wall Street

Duffee, G., 2002, Term Premia and Interest Rate Forecasts in Affine Models, Journal of Finance $57,405-443$

Fama, E., 1970, Efficient Capital Markets: A Review of Theory and Empirical Work, Journal of Finance 25, 383-417

Fama, E., 1991, Efficient Capital Markets: II, Journal of Finance 46, 1575-1617

Fama, E. and French, K., 1993, Common Risk Factors in the Returns on Stocks and Bonds, Journal of Financial Economics 33, 3-56

Fung, W. and Hsieh, D., 2000, Performance Characteristics of Hedge Funds and CTA Funds: Natural versus Spurious Biases, Journal of Financial and Quantitative Analysis 35, 291-307

Fund, W. and Hsieh, D., 2001, The Risk in Hedge Fund Strategies: Theory and Evidence from Trend Followers, Review of Financial Studies 14, 313-341

Fung, W. and Hsieh, D., 2002, Benchmarks of Hedge Fund Performance: Information Content and Measurement Biases, Financial Analyst Journal 58, 22-34

Fung, W. and Hsieh, D., 2004, Hedge Fund Benchmarks: A Risk Based Approach, Financial Analyst Journal 60, 65-80. 
Fung, W., Hsieh, D., Naik N., and Ramadorai T., 2008, Hedge Funds: Performance, Risk and Capital Formation, Journal of Finance 63(4), 1777-1803

Fung, H., Xu, X., Yau, J., 2002, Global hedge funds: risk, return, and market timing, Financial Analysts Journal 58(6), 19-30

Getmansky, M., Lo A., and Makarov I., 2004, An Econometric Model of Serial Correlation and Illiquidity in Hedge Funds Returns, Journal of Financial Economics 74, 529-610

Henriksson, R. and Merton, R., 1981, On market timing and investment performance II.

Statistical procedures for evaluating forecasting skills. Journal of Business 54, 513-533

Jagannathan, R., Malakhov, A., and Novikov, D., 2010, Do Hot Hands Exist among Hedge Fund Managers? An Empirical Evaluation, Journal of Finance 65(1), 217-255

Jensen, M., 1968, The Performance of Mutual Funds in the Period 1945-1964, Journal of Finance 23, 389-416

Jensen, M., 1978, Some Anomalous Evidence Regarding Market Efficiency, Journal of Financial Economics 6, 95-101

Kosowski, R., Naik, N., and Teo, M., 2007, Do Hedge Funds Deliver Alpha?, Journal of Financial Economics 84, 229-264

Liang, B., 2004, Alternative Investments: CTAs, Hedge Funds, and Funds-of-Funds, Journal of Investment Management 2, 76-93

Liang, B. and Park, H., 2010a, Predicting Hedge Fund Failure: A Comparison of Risk Measures, Journal of Financial and Quantitative Analysis 45(1), 199-222

Liang, B., and Park, H., 2010b, Onshore and Offshore Hedge Funds: Are They Twins? Working Paper, University of Massachusetts Amherst

Lo, A., 2008, Where Do Alphas Come From? A Measure of the Value of Active Investment Management, Journal of Investment Management 6(2), 1-29

Nohel, T., Wang, Z. J., and Zheng, L., 2010, Side-by-Side Management of Hedge Funds and Mutual Funds, Review of Financial Studies 23(6), 2342-2373

Pastor, L., and Stambaugh, R., 2002, Mutual Fund Performance and Seemingly Unrelated Assets, Journal of Financial Economics 63, 315-349

Treynor, J. and Mazuy, K., 1966, Can mutual funds outguess the market? Harvard Business Review 44, 131-136

Welch, I. and Goyal, A., 2008, A Comprehensive Look at the Empirical Performance of Equity Premium Prediction, Review of Financial Studies v. 21, n. 4, 1455-1508 


\section{Table 1. Summary Statistics}

Panel A shows the cross-sectional average values of the mean, standard deviation, alpha, and GLM illiquidity $(\varphi)$ of hedge funds, CTAs, and FOFs in the TASS database. To be included in the analysis, funds should have at least twenty four monthly return observations during the sample period between January 1994 and December 2008. Returns are reported in percent per month. Alpha is estimated using the eight-factors in Table 2. Full sample alpha is based on the entire return history of a fund, and alpha adjusted for backfill bias is estimated after deleting the first twenty four monthly return observations. Panel B shows the mean, standard deviation, minimum, maximum, and alpha of daily percentage returns on HFRX indices during the sample period between April 1, 2003 and March 31, 2010. Daily index alpha is estimated using a fivefactor model (MFA, SMB, CSF, CYD, and MSCI) during the period between May 30, 2006 and March 31, 2010. t-statistics are given in square brackets. ***, **, and * denote statistical significance at the 1 percent, 5 percent, and 10 percent level, respectively.

Panel A: Monthly returns on hedge funds, CTAs, and FOFs in TASS database

\begin{tabular}{|c|c|c|c|c|c|c|}
\hline \multirow[b]{2}{*}{ Investment Style } & \multirow[b]{2}{*}{ Number } & \multirow[b]{2}{*}{ Mean } & \multirow{2}{*}{$\begin{array}{l}\text { Standard } \\
\text { Deviation }\end{array}$} & \multicolumn{2}{|c|}{ Alpha } & \multirow{2}{*}{$\begin{array}{l}\text { GLM Illiquidity } \\
\qquad(\varphi)\end{array}$} \\
\hline & & & & Full sample & $\begin{array}{l}\text { After adjusting } \\
\text { for backfill bias }\end{array}$ & \\
\hline $\begin{array}{l}\text { Illiquid-style } \\
\text { Hedge Funds }\end{array}$ & 1322 & 0.70 & 3.67 & $\begin{array}{c}0.48 \\
{[19.85]^{\star \star \star}}\end{array}$ & $\begin{array}{c}0.32 \\
{[13.27]^{\star \star \star}}\end{array}$ & 0.33 \\
\hline Convertible Arbitrage & 175 & 0.47 & 2.41 & $\begin{array}{l}0.29 \\
{[8.26]^{\star \star \star}}\end{array}$ & $\begin{array}{l}0.14 \\
{[3.22]^{\star \star \star}}\end{array}$ & 0.40 \\
\hline Emerging Markets & 365 & 0.72 & 6.23 & $\begin{array}{l}0.62 \\
{[10.42]^{\star \star \star}}\end{array}$ & $\begin{array}{l}0.51 \\
{[7.08]^{\star \star \star}}\end{array}$ & 0.32 \\
\hline Event Driven & 518 & 0.81 & 2.88 & $\begin{array}{c}0.53 \\
{[13.96]^{\star \star \star}}\end{array}$ & $\begin{array}{l}0.33 \\
{[8.26]^{\star \star *}}\end{array}$ & 0.33 \\
\hline $\begin{array}{l}\text { Fixed Income } \\
\text { Arbitrage }\end{array}$ & 264 & 0.51 & 2.37 & $\begin{array}{l}0.31 \\
{[8.11]^{\star \star \star}}\end{array}$ & $\begin{array}{l}0.17 \\
{[3.01]^{\star \star \star}}\end{array}$ & 0.34 \\
\hline $\begin{array}{l}\text { Liquid-style } \\
\text { Hedge Funds }\end{array}$ & 2924 & 0.78 & 4.59 & $\begin{array}{l}0.41 \\
{[8.65]^{\star \star \star}}\end{array}$ & $\begin{array}{l}0.35 \\
{[3.92]^{\star \star *}}\end{array}$ & 0.27 \\
\hline Dedicated Short Bias & 40 & 0.30 & 5.71 & $\begin{array}{c}0.19 \\
{[1.64]}\end{array}$ & $\begin{array}{c}-0.08 \\
{[-0.47]}\end{array}$ & 0.17 \\
\hline Equity Market Neutral & 311 & 0.55 & 2.56 & $\begin{array}{l}0.24 \\
{[6.74]^{\star \star \star}}\end{array}$ & $\begin{array}{l}0.16 \\
{[4.65]^{\star \star \star}}\end{array}$ & 0.29 \\
\hline Global Macro & 287 & 0.59 & 4.16 & $\begin{array}{l}0.25 \\
{[4.72]^{\star \star \star}}\end{array}$ & $\begin{array}{c}0.08 \\
{[0.95]}\end{array}$ & 0.24 \\
\hline $\begin{array}{c}\text { Long/Short Equity } \\
\text { Hedge }\end{array}$ & 1835 & 0.88 & 5.29 & $\begin{array}{l}0.49 \\
{[6.64]^{\star \star \star}}\end{array}$ & $\begin{array}{l}0.44 \\
{[2.69]^{\star \star \star}}\end{array}$ & 0.26 \\
\hline Multi-Strategy & 451 & 0.61 & 3.10 & $\begin{array}{l}0.31 \\
{[8.21]^{\star \star \star}}\end{array}$ & $\begin{array}{l}0.28 \\
{[5.02]^{\star \star *}}\end{array}$ & 0.30 \\
\hline All Hedge Funds & 4246 & 0.74 & 4.26 & $\begin{array}{c}0.43 \\
{[12.90]^{\star \star \star}}\end{array}$ & $\begin{array}{l}0.34 \\
{[4.65]^{\star \star \star}}\end{array}$ & 0.30 \\
\hline CTAs & 476 & 0.86 & 5.91 & $\begin{array}{l}0.49 \\
{[7.92]^{\star \star \star}}\end{array}$ & $\begin{array}{c}0.46 \\
{[4.73]^{\star \star \star}}\end{array}$ & 0.25 \\
\hline Fund of Funds & 1392 & 0.41 & 2.55 & $\begin{array}{l}0.10 \\
{[8.43]^{\star \star \star}}\end{array}$ & $\begin{array}{l}0.06 \\
{[4.46]^{\star \star \star}}\end{array}$ & 0.31 \\
\hline All Funds & 6114 & 0.68 & 4.01 & $\begin{array}{c}0.36 \\
{[15.08]^{\star \star \star}}\end{array}$ & $\begin{array}{l}0.28 \\
{[5.55]^{\star \star \star}}\end{array}$ & 0.30 \\
\hline
\end{tabular}


Panel B: Daily returns on HFRX indices

\begin{tabular}{|c|c|c|c|c|c|c|}
\hline Index & Description & Mean & $\begin{array}{l}\text { Standard } \\
\text { Deviation }\end{array}$ & Minimum & Maximum & Alpha \\
\hline AR & Absolute Return & -0.0018 & 0.1782 & -1.28 & 1.03 & $\begin{array}{c}-0.02 \\
{[-2.95]^{\star \star \star}}\end{array}$ \\
\hline CA & Convertible Arbitrage & -0.0246 & 0.4803 & -6.43 & 3.28 & $\begin{array}{c}-0.05 \\
{[-2.92]}\end{array}$ \\
\hline DS & Distressed Securities & 0.0002 & 0.2598 & -4.24 & 1.73 & $\begin{array}{l}-0.04 \\
{[-3.73]^{\star \star \star}}\end{array}$ \\
\hline ED & Event Driven & 0.0188 & 0.3290 & -3.12 & 2.57 & $\begin{array}{c}-0.01 \\
{[-0.87]}\end{array}$ \\
\hline $\mathrm{EH}$ & Equity Hedge & -0.0008 & 0.4312 & -3.02 & 2.56 & $\begin{array}{c}-0.02 \\
{[-2.07]^{\star \star}}\end{array}$ \\
\hline EMN & Equity Market Neutral & 0.0001 & 0.2800 & -3.09 & 3.10 & $\begin{array}{c}-0.01 \\
{[-0.96]}\end{array}$ \\
\hline EW & Equal Weighted Strategies & 0.0074 & 0.1981 & -1.76 & 1.69 & $\begin{array}{c}-0.01 \\
{[-2.20]^{\star \star}}\end{array}$ \\
\hline GL & $\begin{array}{l}\text { Global (Designed to be } \\
\text { representative of the } \\
\text { overall hedge fund universe) }\end{array}$ & 0.0095 & 0.2632 & -1.95 & 1.89 & $\begin{array}{c}-0.01 \\
{[-1.87]^{\star}}\end{array}$ \\
\hline M & Macro & 0.0140 & 0.4677 & -3.65 & 2.01 & $\begin{array}{c}0.00 \\
{[0.27]}\end{array}$ \\
\hline MA & Merger Arbitrage & 0.0223 & 0.3176 & -2.40 & 5.74 & $\begin{array}{c}0.01 \\
{[1.18]}\end{array}$ \\
\hline MD & Market Directional & 0.0127 & 0.4818 & -3.19 & 3.71 & $\begin{array}{c}-0.01 \\
{[-0.71]}\end{array}$ \\
\hline RVA & Relative Value Arbitrage & 0.0070 & 0.3234 & -3.69 & 3.29 & $\begin{array}{c}-0.01 \\
{[-0.79]}\end{array}$ \\
\hline
\end{tabular}




\section{Table 2. Time Varying Risk Premium}

This table shows the time variation in systematic risk factors during January 1994 to December 2008. MFA is the excess return on the S\&P 500 index, MSCI denotes the excess return on MSCI emerging market index, SMB is the size factor, CYD stands for the monthly change in the 10year treasury constant maturity yield, CSP denotes the change in the credit spread of the Moody's Baa bond over the 10-year treasury bond, and TFFX, TFCOM, and TFBD are the trend-following factors for currencies, commodities, and bonds.

\begin{tabular}{|c|c|c|c|c|c|c|c|c|c|}
\hline \multirow{2}{*}{$\begin{array}{l}\text { Risk } \\
\text { Factors }\end{array}$} & & \multicolumn{8}{|c|}{ Time Variation in Average Values of Systematic Risk Factors (\% per month) } \\
\hline & $\begin{array}{c}\begin{array}{c}\text { Sub- } \\
\text { period } 1\end{array} \\
1994-95\end{array}$ & $\begin{array}{c}\begin{array}{c}\text { Sub- } \\
\text { period } 2\end{array} \\
1996-97\end{array}$ & $\begin{array}{c}\begin{array}{c}\text { Sub- } \\
\text { period } 3\end{array} \\
1998-99\end{array}$ & $\begin{array}{c}\text { Sub- } \\
\text { period } 4\end{array}$ & $\begin{array}{c}\begin{array}{c}\text { Sub- } \\
\text { period } 5\end{array} \\
2002-03\end{array}$ & $\begin{array}{c}\begin{array}{c}\text { Sub- } \\
\text { period } 6\end{array} \\
2004-05\end{array}$ & $\begin{array}{c}\text { Sub- } \\
\text { period } 7\end{array}$ & $\begin{array}{c}\text { '94-’08 } \\
\text { Average }\end{array}$ & $\begin{array}{l}\text { ‘94-‘08 } \\
\text { Standard }\end{array}$ \\
\hline MFA & 0.78 & 1.55 & 1.47 & -1.29 & -0.12 & 0.31 & -1.09 & 0.14 & 4.30 \\
\hline SMB & -0.29 & -0.20 & -0.34 & 0.84 & 1.03 & 0.15 & 0.01 & 0.16 & 3.77 \\
\hline CSF & -0.19 & -0.64 & 1.25 & 2.09 & -0.89 & -0.84 & 3.69 & 0.84 & 6.68 \\
\hline CYD & 0.03 & 0.13 & 0.41 & -0.78 & -0.53 & 0.30 & -1.44 & -0.35 & 5.12 \\
\hline $\mathrm{MSCl}$ & -0.97 & -0.71 & 0.82 & -1.93 & 1.43 & 1.90 & -0.54 & -0.04 & 6.99 \\
\hline TFBD & 1.60 & -0.92 & 3.63 & 1.91 & -0.81 & -8.58 & -1.89 & -0.80 & 14.89 \\
\hline TFFX & -2.78 & 0.92 & -1.64 & -1.25 & 4.20 & -0.44 & 4.90 & 0.85 & 19.91 \\
\hline TFCOM & -5.40 & 4.20 & 2.07 & -4.23 & -1.58 & 0.36 & 3.96 & 0.18 & 14.05 \\
\hline
\end{tabular}




\section{Table 3. Time-varying Beta}

In each of the seven sub-periods between 1994 and 2008, an eight-factor model is estimated for an equally weighted portfolio of all hedge funds in the database. This table shows how hedge fund beta for each of the eight risk factors has changed over time. This table also shows the alpha and the adjusted R square of the eight-factor model for each sub-period.

\begin{tabular}{|c|c|c|c|c|c|c|c|c|}
\hline \multirow{3}{*}{$\begin{array}{l}\text { Betas for Eight } \\
\text { Risk Factors, } \\
\text { Alpha, and } \\
\text { Adjusted-R }{ }^{2}\end{array}$} & \multicolumn{8}{|c|}{$\begin{array}{l}\text { Time Series of Beta, } \\
\text { Alpha, and Adjusted-R }\end{array}$} \\
\hline & $\begin{array}{l}\text { Sub- } \\
\text { period } 1\end{array}$ & $\begin{array}{c}\text { Sub- } \\
\text { period } 2\end{array}$ & $\begin{array}{c}\text { Sub- } \\
\text { period } 3\end{array}$ & $\begin{array}{c}\text { Sub- } \\
\text { period } 4\end{array}$ & $\begin{array}{l}\text { Sub- } \\
\text { period } 5\end{array}$ & $\begin{array}{l}\text { Sub- } \\
\text { period } 6\end{array}$ & $\begin{array}{c}\text { Sub- } \\
\text { period } 7\end{array}$ & \multirow[t]{2}{*}{ Average } \\
\hline & 1994-95 & $1996-97$ & $1998-99$ & $2000-01$ & $2002-03$ & $2004-05$ & $2006-08$ & \\
\hline \multicolumn{9}{|l|}{ Betas } \\
\hline MFA & $0.20^{\star \star}$ & $0.18^{\star \star \star}$ & $0.22^{\star \star \star}$ & $0.21^{\star \star \star}$ & $0.08 *$ & -0.08 & 0.07 & 0.12 \\
\hline SMB & $0.22^{\star \star}$ &  & $0.20^{* \star \star}$ & 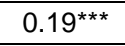 & $0.07^{*}$ & $0.20^{\star \star \star}$ & -0.02 & 0.16 \\
\hline CSF & 0.05 & $-0.17^{\star \star}$ & $-0.17^{\star \star \star}$ & 0.04 & $-0.09 * \star \star$ & $-0.04^{\star}$ & -0.02 & -0.06 \\
\hline CYD & -0.04 & -0.10 & $-0.13^{\star \star}$ & 0.02 & $-0.08^{\star \star \star}$ & 0.01 & $0.07^{\star \star}$ & -0.04 \\
\hline $\mathrm{MSCl}$ & $0.11^{\star \star}$ & $0.14^{\star \star \star}$ & $0.14^{\star \star \star}$ & 0.05 & $0.15^{\star \star \star}$ & $0.22^{\star \star \star}$ & $0.24^{\star \star \star}$ & 0.15 \\
\hline TFBD & -0.01 & $0.03^{\star \star}$ & 0.00 & 0.00 & 0.00 & 0.01 & 0.00 & 0.00 \\
\hline TFFX & 0.01 & 0.01 & -0.01 & $0.03^{*}$ & 0.00 & 0.00 & 0.00 & 0.01 \\
\hline TFCOM & -0.01 & 0.01 & 0.00 & 0.00 & $0.02^{\star \star}$ & 0.00 & 0.01 & 0.00 \\
\hline Alpha & $0.45^{\star *}$ & $1.01^{\star \star \star}$ & $0.85^{\star \star \star}$ & $0.59^{* *}$ & $0.41^{* * *}$ & 0.23 & 0.21 & 0.54 \\
\hline Adj-R ${ }^{2}(\%)$ & 78.98 & 89.92 & 96.75 & 85.35 & 91.66 & 90.77 & 87.54 & 88.71 \\
\hline
\end{tabular}


Table 4. Factor Timing Ability of Hedge Funds, CTAs, and FoFs (Portfolio-Level Test)

Using an equally weighted portfolio formed for each investment style, an eight-factor model is estimated for each of the seven sub-periods between 1994 and 2008. Then the time series beta is used to find the covariance between beta and factor risk premium. The numbers reported in the table are the covariance estimates, and correlation coefficients are given in parentheses. The critical value table for Pearson's correlation coefficient is used to test the significance of estimated correlation coefficients. ${ }^{* * *}, * *$, and $*$ denote statistical significance at the 1 percent, 5 percent, and 10 percent level, respectively.

\begin{tabular}{|c|c|c|c|c|c|c|c|c|c|}
\hline $\begin{array}{l}\text { Investment } \\
\text { Style }\end{array}$ & $\begin{array}{c}\text { Number } \\
\text { of } \\
\text { Funds }\end{array}$ & MFA & SMB & CSF & CYD & $\mathrm{MSCl}$ & TFBD & TFFX & TFCOM \\
\hline $\begin{array}{l}\text { Illiquid-Style } \\
\text { Hedge Funds }\end{array}$ & 1322 & $\begin{array}{c}-0.02 \\
(-0.43)\end{array}$ & $\begin{array}{c}-0.02 \\
(-0.59)\end{array}$ & $\begin{array}{l}0.03 \\
(0.26)\end{array}$ & $\begin{array}{c}-0.02 \\
(-0.43)\end{array}$ & $\begin{array}{c}-0.02 \\
(-0.34)\end{array}$ & $\begin{array}{l}-0.03 \\
(-0.61)\end{array}$ & $\begin{array}{c}0.00 \\
(-0.05)\end{array}$ & $\begin{array}{c}0.01 \\
(0.24)\end{array}$ \\
\hline $\begin{array}{l}\text { Convertible } \\
\text { Arbitrage } \\
\text { Emerging } \\
\text { Markets }\end{array}$ & 175 & $\begin{array}{c}-0.04 \\
(-0.12) \\
-0.09 \\
(-0.46)\end{array}$ & $\begin{array}{c}0.00 \\
(0.02) \\
-0.04 \\
(-0.51)\end{array}$ & $\begin{array}{c}-0.06 \\
(-0.57) \\
0.07 \\
(0.29)\end{array}$ & $\begin{array}{c}0.00 \\
(-0.02) \\
-0.03 \\
(-0.40)\end{array}$ & $\begin{array}{c}-0.04 \\
(-0.33) \\
0.01 \\
(0.07)\end{array}$ & $\begin{array}{c}-0.06 \\
(-0.32) \\
-0.02 \\
(-0.32)\end{array}$ & $\begin{array}{l}-0.02 \\
(-0.79)^{\star *} \\
-0.01 \\
(-0.22)\end{array}$ & $\begin{array}{c}-0.01 \\
(-0.20) \\
0.01 \\
(0.06)\end{array}$ \\
\hline Event Driven & 518 & $\begin{array}{l}0.02 \\
(0.26)\end{array}$ & $\begin{array}{l}-0.02 \\
(-0.82)^{\star \star}\end{array}$ & $\begin{array}{c}0.03 \\
(0.29)\end{array}$ & $\begin{array}{l}-0.02 \\
(-0.42)\end{array}$ & $\begin{array}{c}0.01 \\
(0.26)\end{array}$ & $\begin{array}{l}-0.04 \\
(-0.69)^{\star}\end{array}$ & $\begin{array}{c}0.00 \\
(0.34)\end{array}$ & $\begin{array}{c}0.01 \\
(0.34)\end{array}$ \\
\hline $\begin{array}{l}\text { Fixed Income } \\
\text { Arbitrage }\end{array}$ & 264 & $\begin{array}{c}-0.01 \\
(-0.14) \\
\end{array}$ & $\begin{array}{r}0.00 \\
(0.06) \\
\end{array}$ & $\begin{array}{c}-0.04 \\
(-0.31) \\
\end{array}$ & $\begin{array}{c}0.00 \\
(-0.08) \\
\end{array}$ & $\begin{array}{l}-0.02 \\
(-0.40) \\
\end{array}$ & $\begin{array}{r}0.02 \\
(0.43) \\
\end{array}$ & $\begin{array}{c}0.02 \\
(0.33) \\
\end{array}$ & $\begin{array}{c}0.05 \\
(0.51) \\
\end{array}$ \\
\hline $\begin{array}{l}\text { Liquid-Style } \\
\text { Hedge Funds }\end{array}$ & 2924 & $\begin{array}{l}0.06 \\
(0.37)\end{array}$ & $\begin{array}{c}-0.02 \\
(-0.31)\end{array}$ & $\begin{array}{c}0.04 \\
(0.29)\end{array}$ & $\begin{array}{l}-0.04 \\
(-0.64)\end{array}$ & $\begin{array}{c}0.07 \\
(0.62)\end{array}$ & $\begin{array}{c}-0.01 \\
(-0.15)\end{array}$ & $\begin{array}{c}-0.01 \\
(-0.30)\end{array}$ & $\begin{array}{c}0.02 \\
(0.42)\end{array}$ \\
\hline $\begin{array}{l}\text { Dedicated } \\
\text { Short Bias }\end{array}$ & 40 & $\begin{array}{c}-0.04 \\
(-0.16)\end{array}$ & $\begin{array}{c}0.07 \\
(0.43)\end{array}$ & $\begin{array}{c}0.03 \\
(0.17)\end{array}$ & $\begin{array}{c}-0.01 \\
(-0.05)\end{array}$ & $\begin{array}{c}-0.06 \\
(-0.45)\end{array}$ & $\begin{array}{l}0.12 \\
(0.77)^{\star \star}\end{array}$ & $\begin{array}{c}0.05 \\
(0.48)\end{array}$ & $\begin{array}{c}0.02 \\
(0.11)\end{array}$ \\
\hline $\begin{array}{l}\text { Equity Market } \\
\text { Neutral }\end{array}$ & 311 & $\begin{array}{c}0.05 \\
(0.52)\end{array}$ & $\begin{array}{l}-0.01 \\
(-0.50)\end{array}$ & $\begin{array}{l}0.06 \\
(0.89)^{\star \star \star}\end{array}$ & $\begin{array}{l}-0.04 \\
(-0.63)\end{array}$ & $\begin{array}{c}0.02 \\
(0.34)\end{array}$ & $\begin{array}{c}0.02 \\
(0.44)\end{array}$ & $\begin{array}{l}-0.01 \\
(-0.28)\end{array}$ & $\begin{array}{l}0.00 \\
(0.00)\end{array}$ \\
\hline Global Macro & 287 & $\begin{array}{c}0.06 \\
(0.81)^{\star \star}\end{array}$ & $\begin{array}{c}0.02 \\
(0.44)\end{array}$ & $\begin{array}{c}0.03 \\
(0.17)\end{array}$ & $\begin{array}{c}-0.04 \\
(-0.58)\end{array}$ & $\begin{array}{c}0.02 \\
(0.26)\end{array}$ & $\begin{array}{c}0.02 \\
(0.23)\end{array}$ & $\begin{array}{c}-0.03 \\
(-0.39)\end{array}$ & $\begin{array}{c}0.02 \\
(0.18)\end{array}$ \\
\hline $\begin{array}{l}\text { Long/Short } \\
\text { Equity Hedge }\end{array}$ & 1835 & $\begin{array}{r}0.07 \\
(0.34)\end{array}$ & $\begin{array}{l}-0.03 \\
(-0.34)\end{array}$ & $\begin{array}{c}0.05 \\
(0.28)\end{array}$ & $\begin{array}{l}-0.04 \\
(-0.57)\end{array}$ & $\begin{array}{c}0.11 \\
(0.65)\end{array}$ & $\begin{array}{l}-0.02 \\
(-0.24)\end{array}$ & $\begin{array}{c}-0.01 \\
(-0.26)\end{array}$ & $\begin{array}{c}0.02 \\
(0.40)\end{array}$ \\
\hline Multi-Strategy & 451 & $\begin{array}{r}0.03 \\
(0.29)\end{array}$ & $\begin{array}{c}-0.01 \\
(-0.21)\end{array}$ & $\begin{array}{c}0.02 \\
(0.22)\end{array}$ & $\begin{array}{l}-0.02 \\
(-0.67)^{\star}\end{array}$ & $\begin{array}{c}0.03 \\
(0.34)\end{array}$ & $\begin{array}{c}-0.01 \\
(-0.33)\end{array}$ & $\begin{array}{c}0.00 \\
(-0.05)\end{array}$ & $\begin{array}{c}0.01 \\
(0.29)\end{array}$ \\
\hline $\begin{array}{l}\text { All Hedge } \\
\text { Funds }\end{array}$ & 4246 & $\begin{array}{r}0.03 \\
(0.23)\end{array}$ & $\begin{array}{l}-0.02 \\
(-0.36)\end{array}$ & $\begin{array}{c}0.04 \\
(0.29)\end{array}$ & $\begin{array}{l}-0.03 \\
(-0.71)^{\star \star}\end{array}$ & $\begin{array}{c}0.04 \\
(0.55)\end{array}$ & $\begin{array}{l}-0.02 \\
(-0.33)\end{array}$ & $\begin{array}{r}-0.01 \\
(-0.27)\end{array}$ & $\begin{array}{c}0.02 \\
(0.43)\end{array}$ \\
\hline CTAs & 476 & $\begin{array}{r}0.12 \\
(0.42)\end{array}$ & $\begin{array}{c}0.00 \\
(0.00)\end{array}$ & $\begin{array}{c}0.07 \\
(0.32)\end{array}$ & $\begin{array}{c}-0.07 \\
(-0.51)\end{array}$ & $\begin{array}{c}-0.03 \\
(-0.19)\end{array}$ & $\begin{array}{c}0.11 \\
(0.63) \\
\end{array}$ & $\begin{array}{r}0.00 \\
(-0.03) \\
\end{array}$ & $\begin{array}{c}0.02 \\
(0.14) \\
\end{array}$ \\
\hline Fund of Funds & 1392 & $\begin{array}{r}0.03 \\
(0.36) \\
\end{array}$ & $\begin{array}{c}-0.01 \\
(-0.40)\end{array}$ & $\begin{array}{c}0.02 \\
(0.16)\end{array}$ & $\begin{array}{c}-0.04 \\
(-0.71)^{\star \star}\end{array}$ & $\begin{array}{c}0.03 \\
(0.37) \\
\end{array}$ & $\begin{array}{c}0.00 \\
(-0.09)\end{array}$ & $\begin{array}{c}-0.01 \\
(-0.19) \\
\end{array}$ & $\begin{array}{l}-0.01 \\
(-0.15)\end{array}$ \\
\hline All Funds & 6114 & $\begin{array}{r}0.03 \\
(0.33)\end{array}$ & $\begin{array}{l}-0.01 \\
(-0.24)\end{array}$ & $\begin{array}{c}0.03 \\
(0.25)\end{array}$ & $\begin{array}{c}-0.03 \\
(-0.69)^{\star}\end{array}$ & $\begin{array}{c}0.04 \\
(0.46)\end{array}$ & $\begin{array}{c}0.00 \\
(0.01)\end{array}$ & $\begin{array}{c}-0.01 \\
(-0.20)\end{array}$ & $\begin{array}{c}0.01 \\
(0.22)\end{array}$ \\
\hline
\end{tabular}




\section{Table 5. Test of Factor Timing Ability (Fund-Level Test)}

For each of the seven sub-periods between 1994 and 2008, an eight-factor model is estimated for each fund. Then the time series beta of each fund is used to find the covariance between beta and factor risk premium for each risk factor. The numbers reported in this table are the crosssectional average values of covariance between beta and factor risk premium. To provide the covariance based on the time series of beta, each fund should have eight years or longer return history (beta estimates for four or more sub-periods) during $1994-2008$. To test the significance of covariance, $t$-test is used. The $t$-statistics are given in square brackets. ${ }^{* * *}$, ${ }^{* *}$, and $*$ denote statistical significance at the 1 percent, 5 percent, and 10 percent level, respectively.

\begin{tabular}{|c|c|c|c|c|c|c|c|c|c|}
\hline $\begin{array}{l}\text { Investment } \\
\text { Style }\end{array}$ & $\begin{array}{c}\text { Number } \\
\text { of } \\
\text { Funds }\end{array}$ & MFA & SMB & CSF & CYD & $\mathrm{MSCl}$ & TFBD & TFFX & TFCOM \\
\hline $\begin{array}{l}\text { Illiquid-Style } \\
\text { Hedge Funds }\end{array}$ & 330 & $\begin{array}{c}-0.03 \\
{[-3.42]^{\star \star \star}}\end{array}$ & $\begin{array}{l}-0.02 \\
{[-5.44]^{\star \star \star}}\end{array}$ & $\begin{array}{l}0.05 \\
{[6.00]^{\star \star \star}}\end{array}$ & $\begin{array}{c}0.00 \\
{[0.72]}\end{array}$ & $\begin{array}{c}0.02 \\
{[1.58]}\end{array}$ & $\begin{array}{l}-0.03 \\
{[-3.75]^{\star \star \star}}\end{array}$ & $\begin{array}{l}-0.01 \\
{[-2.77]^{\star \star \star}}\end{array}$ & $\begin{array}{c}-0.01 \\
{[-1.61]}\end{array}$ \\
\hline $\begin{array}{l}\text { Convertible } \\
\text { Arbitrage }\end{array}$ & 52 & $\begin{array}{r}-0.01 \\
{[-0.43]}\end{array}$ & $\begin{array}{c}-0.01 \\
{[-1.53]}\end{array}$ & $\begin{array}{l}0.06 \\
{[3.69]^{\star \star \star}}\end{array}$ & $\begin{array}{c}0.00 \\
{[0.30]}\end{array}$ & $\begin{array}{l}-0.11 \\
{[-4.52]^{\star \star \star}}\end{array}$ & $\begin{array}{l}-0.05 \\
{[-3.95]^{\star \star \star}}\end{array}$ & $\begin{array}{c}0.00 \\
{[0.27]}\end{array}$ & $\begin{array}{c}-0.01 \\
{[-1.17]}\end{array}$ \\
\hline $\begin{array}{l}\text { Emerging } \\
\text { Markets }\end{array}$ & 105 & $\begin{array}{c}-0.09 \\
{[-4.36]^{\star \star \star}}\end{array}$ & $\begin{array}{l}-0.03 \\
{[-2.92]^{\star \star \star}}\end{array}$ & $\begin{array}{l}0.05 \\
{[2.43]^{\star \star \star}}\end{array}$ & $\begin{array}{c}0.03 \\
{[1.97]^{\star}}\end{array}$ & $\begin{array}{l}0.08 \\
{[3.36]^{\star \star \star}}\end{array}$ & $\begin{array}{c}-0.01 \\
{[-0.51]}\end{array}$ & $\begin{array}{l}-0.04 \\
{[-3.99]^{\star \star \star}}\end{array}$ & $\begin{array}{l}-0.04 \\
{[-2.85]^{\star \star \star}}\end{array}$ \\
\hline Event Driven & 130 & $\begin{array}{c}0.00 \\
{[0.05]}\end{array}$ & $\begin{array}{l}-0.02 \\
{[-6.43]^{\star \star \star}}\end{array}$ & $\begin{array}{l}0.06 \\
{[7.93]^{\star \star \star}}\end{array}$ & $\begin{array}{c}-0.01 \\
{[-2.08]^{\star \star}}\end{array}$ & $\begin{array}{l}0.02 \\
{[2.17]^{\star \star}}\end{array}$ & $\begin{array}{l}-0.06 \\
{[-6.48]^{\star \star \star}}\end{array}$ & $\begin{array}{c}0.00 \\
{[0.88]}\end{array}$ & $\begin{array}{c}0.01 \\
{[1.48]}\end{array}$ \\
\hline $\begin{array}{l}\text { Fixed Income } \\
\text { Arbitrage }\end{array}$ & 43 & $\begin{array}{c}0.01 \\
{[0.89]}\end{array}$ & $\begin{array}{c}0.00 \\
{[0.70]} \\
\end{array}$ & $\begin{array}{c}-0.01 \\
{[-0.51]}\end{array}$ & $\begin{array}{c}0.00 \\
{[0.47]}\end{array}$ & $\begin{array}{c}0.00 \\
{[0.73]}\end{array}$ & $\begin{array}{c}0.02 \\
{[1.54]} \\
\end{array}$ & $\begin{array}{l}0.02 \\
{[2.03]^{\star \star}}\end{array}$ & $\begin{array}{c}0.02 \\
{[0.98]}\end{array}$ \\
\hline $\begin{array}{l}\text { Liquid-Style } \\
\text { Hedge Funds }\end{array}$ & 576 & $\begin{array}{c}0.02 \\
{[1.95]^{\star}}\end{array}$ & $\begin{array}{l}-0.02 \\
{[-5.39]^{\star \star \star}}\end{array}$ & $\begin{array}{l}0.06 \\
{[8.64]^{\star \star \star}}\end{array}$ & $\begin{array}{l}-0.03 \\
{[-7.58]^{\star \star \star}}\end{array}$ & $\begin{array}{l}0.06 \\
{[6.19]^{\star \star \star}}\end{array}$ & $\begin{array}{c}-0.01 \\
{[-1.03]}\end{array}$ & $\begin{array}{l}-0.01 \\
{[-3.94]^{\star \star \star}}\end{array}$ & $\begin{array}{c}0.00 \\
{[0.85]}\end{array}$ \\
\hline $\begin{array}{l}\text { Dedicated } \\
\text { Short Bias }\end{array}$ & 13 & $\begin{array}{l}0.17 \\
{[4.06]^{\star \star \star}}\end{array}$ & $\begin{array}{c}0.00 \\
{[0.12]}\end{array}$ & $\begin{array}{c}0.06 \\
{[1.49]}\end{array}$ & $\begin{array}{l}0.05 \\
{[2.88]^{\star \star}}\end{array}$ & $\begin{array}{c}-0.21 \\
{[-3.21]^{\star \star \star}}\end{array}$ & $\begin{array}{c}0.10 \\
{[1.91]^{\star}}\end{array}$ & $\begin{array}{l}0.99 \\
{[3.99]^{\star \star \star}}\end{array}$ & $\begin{array}{c}0.12 \\
{[1.49]}\end{array}$ \\
\hline $\begin{array}{l}\text { Equity Market } \\
\text { Neutral }\end{array}$ & 49 & $\begin{array}{c}0.02 \\
{[1.12]}\end{array}$ & $\begin{array}{c}-0.01 \\
{[-1.34]}\end{array}$ & $\begin{array}{l}0.07 \\
{[4.95]^{\star \star \star}}\end{array}$ & $\begin{array}{c}-0.03 \\
{[-1.97]^{\star}}\end{array}$ & $\begin{array}{c}0.01 \\
{[0.41]}\end{array}$ & $\begin{array}{c}0.03 \\
{[1.18]}\end{array}$ & $\begin{array}{c}-0.01 \\
{[-0.51]}\end{array}$ & $\begin{array}{c}0.01 \\
{[0.90]}\end{array}$ \\
\hline Global Macro & 43 & $\begin{array}{l}0.04 \\
{[3.27]^{\star \star \star}}\end{array}$ & $\begin{array}{c}0.01 \\
{[1.25]}\end{array}$ & $\begin{array}{l}0.05 \\
{[1.80]^{\star}}\end{array}$ & $\begin{array}{c}-0.02 \\
{[-2.56]^{\star \star}}\end{array}$ & $\begin{array}{c}0.05 \\
{[1.90]^{*}}\end{array}$ & $\begin{array}{c}0.01 \\
{[0.61]}\end{array}$ & $\begin{array}{c}-0.01 \\
{[-1.72]^{*}}\end{array}$ & $\begin{array}{c}-0.01 \\
{[-0.70]}\end{array}$ \\
\hline $\begin{array}{l}\text { Long/Short } \\
\text { Equity Hedge }\end{array}$ & 378 & $\begin{array}{c}0.01 \\
{[0.47]}\end{array}$ & $\begin{array}{l}-0.03 \\
{[-5.49]^{\star \star \star}}\end{array}$ & $\begin{array}{l}0.07 \\
{[6.66]^{\star \star \star}}\end{array}$ & $\begin{array}{l}-0.04 \\
{[-7.61]^{\star \star \star}}\end{array}$ & $\begin{array}{l}0.09 \\
{[6.73]^{\star \star \star}}\end{array}$ & $\begin{array}{c}-0.01 \\
{[-1.46]}\end{array}$ & $\begin{array}{l}-0.02 \\
{[-4.53]^{\star \star \star}}\end{array}$ & $\begin{array}{c}0.00 \\
{[0.55]}\end{array}$ \\
\hline Multi-Strategy & 93 & $\begin{array}{c}0.02 \\
{[1.78]^{\star}}\end{array}$ & $\begin{array}{l}-0.01 \\
{[-2.21]^{\star \star}}\end{array}$ & $\begin{array}{l}0.05 \\
{[4.43]^{\star \star \star}}\end{array}$ & $\begin{array}{c}-0.01 \\
{[-0.87]}\end{array}$ & $\begin{array}{c}0.02 \\
{[1.05]}\end{array}$ & $\begin{array}{c}-0.02 \\
{[-1.51]}\end{array}$ & $\begin{array}{c}-0.01 \\
{[-1.02]}\end{array}$ & $\begin{array}{c}-0.01 \\
{[-0.88]}\end{array}$ \\
\hline $\begin{array}{l}\text { All Hedge } \\
\text { Funds }\end{array}$ & 906 & $\begin{array}{r}0.00 \\
{[0.03]}\end{array}$ & $\begin{array}{l}-0.02 \\
{[-7.41]^{\star \star \star}}\end{array}$ & $\begin{array}{c}0.06 \\
{[10.50]^{\star \star \star}}\end{array}$ & $\begin{array}{l}-0.02 \\
{[-5.63]^{\star \star \star}}\end{array}$ & $\begin{array}{l}0.05 \\
{[6.17]^{\star \star \star}}\end{array}$ & $\begin{array}{l}-0.02 \\
{[-2.98]^{\star \star \star}}\end{array}$ & $\begin{array}{l}-0.01 \\
{[-4.79]^{\star \star \star}}\end{array}$ & $\begin{array}{c}0.00 \\
{[0.32]}\end{array}$ \\
\hline CTAS & 123 & $\begin{array}{c}0.08 \\
{[2.53]^{\star \star \star}}\end{array}$ & $\begin{array}{c}-0.09 \\
{[-0.28]}\end{array}$ & $\begin{array}{l}0.07 \\
{[1.88]^{\star}}\end{array}$ & $\begin{array}{l}-0.05 \\
{[-3.75]^{\star \star \star}}\end{array}$ & $\begin{array}{c}-0.06 \\
{[-0.91]}\end{array}$ & $\begin{array}{l}0.15 \\
{[3.82]^{\star \star \star}}\end{array}$ & $\begin{array}{c}-0.01 \\
{[-0.71]}\end{array}$ & $\begin{array}{c}0.02 \\
{[0.90]}\end{array}$ \\
\hline Fund of Funds & 328 & $\begin{array}{r}0.01 \\
{[0.73]}\end{array}$ & $\begin{array}{l}-0.02 \\
{[-9.17]^{\star \star \star}}\end{array}$ & $\begin{array}{l}0.04 \\
{[7.00]^{\star \star \star}}\end{array}$ & $\begin{array}{l}-0.03 \\
{[-7.55]^{\star \star \star}}\end{array}$ & $\begin{array}{l}0.05 \\
{[3.79]^{\star \star \star}}\end{array}$ & $\begin{array}{l}-0.01 \\
{[-2.25]^{\star \star}}\end{array}$ & $\begin{array}{l}-0.01 \\
{[-3.66]^{\star \star \star}}\end{array}$ & $\begin{array}{c}-0.01 \\
{[-2.80]^{\star \star \star}}\end{array}$ \\
\hline
\end{tabular}




\section{Table 6. Factor Timing of HFRX Indices}

This table shows the covariance between factor risk premium and factor loading of HRRX indices. In every quarter during the 28-quarter period between April 1, 2003 and March 31, 2010, a factor model is estimated using daily return on HFRX indices. Five risk factors (MFA, $\mathrm{SMB}, \mathrm{CSF}, \mathrm{CYD}$, and MSCI) are used in the regressions. Then the 28 factor loadings of an index for a factor and factor risk premium are used to find the covariance that represents the factor timing ability of the index. As the MSCI factor data is available from May 30, 2006, this factor is not included in the regression model during the first thirteen quarters (2003 Q2-4, 2004, 2005, and 2006 Q1-2). The numbers reported in this table are covariance estimates, and correlation coefficients are written in parentheses. The significance of correlation coefficient is tested using the critical value table for Pearson's correlation coefficient. ${ }^{* * *}$, **, and $*$ denote statistical significance at the 1 percent, 5 percent, and 10 percent level, respectively.

\begin{tabular}{|c|c|c|c|c|c|c|}
\hline Index & Description & MFA & SMB & CSF & CYD & $\mathrm{MSCl}$ \\
\hline AR & $\begin{array}{l}\text { Absolute Return (Designed to } \\
\text { be representative of the overall } \\
\text { hedge fund universe) }\end{array}$ & $\begin{array}{c}-0.0014 \\
(-0.18)\end{array}$ & $\begin{array}{l}0.0007 \\
(0.22)\end{array}$ & $\begin{array}{c}-0.0044 \\
(-0.58)^{\star \star \star}\end{array}$ & $\begin{array}{c}0.0005 \\
(0.12)\end{array}$ & $\begin{array}{c}-0.0009 \\
(-0.12)\end{array}$ \\
\hline CA & Convertible Arbitrage & $\begin{array}{c}-0.0004 \\
(-0.07)\end{array}$ & $\begin{array}{c}0.0007 \\
(0.15)\end{array}$ & $\begin{array}{c}-0.0087 \\
(-0.37)^{\star}\end{array}$ & $\begin{array}{c}0.0031 \\
(0.26)\end{array}$ & $\begin{array}{l}-0.0089 \\
(-0.58)^{\star \star}\end{array}$ \\
\hline DS & Distressed Securities & $\begin{array}{c}0.0012 \\
(0.16)\end{array}$ & $\begin{array}{c}0.0007 \\
(0.23)\end{array}$ & $\begin{array}{r}-0.0012 \\
(-0.12)\end{array}$ & $\begin{array}{c}0.0014 \\
(0.29)\end{array}$ & $\begin{array}{c}-0.0011 \\
(-0.24)\end{array}$ \\
\hline ED & Event Driven & $\begin{array}{c}-0.0006 \\
(-0.05)\end{array}$ & $\begin{array}{l}0.0005 \\
(0.12)\end{array}$ & $\begin{array}{r}-0.0012 \\
(-0.14)\end{array}$ & $\begin{array}{c}0.0007 \\
(0.13)\end{array}$ & $\begin{array}{c}-0.0034 \\
(-0.36)\end{array}$ \\
\hline $\mathrm{EH}$ & Equity Hedge & $\begin{array}{c}-0.0002 \\
(-0.02)\end{array}$ & $\begin{array}{r}-0.0005 \\
(-0.09)\end{array}$ & $\begin{array}{r}-0.0019 \\
(-0.27)\end{array}$ & $\begin{array}{c}0.0006 \\
(0.15)\end{array}$ & $\begin{array}{l}0.0022 \\
(0.27)\end{array}$ \\
\hline EMN & Equity Market Neutral & $\begin{array}{l}0.0008 \\
(0.08)\end{array}$ & $\begin{array}{l}0.0028 \\
(0.38)^{\star \star}\end{array}$ & $\begin{array}{r}-0.0004 \\
(-0.04)\end{array}$ & $\begin{array}{c}0.0014 \\
(0.17)\end{array}$ & $\begin{array}{l}0.0023 \\
(0.19)\end{array}$ \\
\hline EW & Equal Weighted Strategies & $\begin{array}{c}-0.0001 \\
(-0.02)\end{array}$ & $\begin{array}{c}0.0005 \\
(0.19)\end{array}$ & $\begin{array}{l}-0.0030 \\
(-0.47)^{\star \star}\end{array}$ & $\begin{array}{c}0.0014 \\
(0.36)^{\star}\end{array}$ & $\begin{array}{c}-0.0003 \\
(-0.03)\end{array}$ \\
\hline $\mathrm{GL}$ & $\begin{array}{l}\text { Global (Designed to be } \\
\text { representative of the overall hedge } \\
\text { fund universe) }\end{array}$ & $\begin{array}{c}0.0000 \\
(0.00)\end{array}$ & $\begin{array}{c}0.0001 \\
(0.04)\end{array}$ & $\begin{array}{l}-0.0030 \\
(-0.48)^{\star \star}\end{array}$ & $\begin{array}{c}0.0011 \\
(0.26)\end{array}$ & $\begin{array}{l}0.0002 \\
(0.03)\end{array}$ \\
\hline M & Macro & $\begin{array}{c}0.0018 \\
(0.14)\end{array}$ & $\begin{array}{c}0.0010 \\
(0.14)\end{array}$ & $\begin{array}{r}-0.0033 \\
(-0.20)\end{array}$ & $\begin{array}{c}0.0028 \\
(0.15)\end{array}$ & $\begin{array}{l}0.0107 \\
(0.30)\end{array}$ \\
\hline MA & Merger Arbitrage & $\begin{array}{c}-0.0025 \\
(-0.32)^{\star}\end{array}$ & $\begin{array}{l}-0.0015 \\
(-0.48)^{\star \star}\end{array}$ & $\begin{array}{r}-0.0023 \\
(-0.26)\end{array}$ & $\begin{array}{c}0.0009 \\
(0.21)\end{array}$ & $\begin{array}{c}-0.0004 \\
(-0.08)\end{array}$ \\
\hline MD & Market Directional & $\begin{array}{c}0.0006 \\
(0.03)\end{array}$ & $\begin{array}{r}-0.0007 \\
(-0.12)\end{array}$ & $\begin{array}{r}-0.0023 \\
(-0.19)\end{array}$ & $\begin{array}{c}0.0025 \\
(0.22)\end{array}$ & $\begin{array}{l}0.0003 \\
(0.02)\end{array}$ \\
\hline RVA & Relative Value Arbitrage & $\begin{array}{c}-0.0006 \\
(-0.08)\end{array}$ & $\begin{array}{c}-0.0003 \\
(-0.08)\end{array}$ & $\begin{array}{l}-0.0071 \\
(-0.55)^{\star \star \star}\end{array}$ & $\begin{array}{c}0.0007 \\
(0.13)\end{array}$ & $\begin{array}{l}-0.0064 \\
(-0.67)^{\star \star \star}\end{array}$ \\
\hline
\end{tabular}




\section{Table 7. Decomposition of Excess Return (Portfolio-Level Test)}

This table shows how much of the excess return generated by hedge funds, CTAs, and FoFs during 1994 - 2008 are from security selection, factor timing, and risk premium. The unit of return is percent per month, and the numbers inside parentheses show the percentages of excess return generated by security selection, factor timing, and risk premium. The total percentages are written inside parentheses in the excess return column. If the excess return is positive, the total percentage is $100 \%$. The total percentage is $-100 \%$ if the excess return is negative.

\begin{tabular}{|c|c|c|c|c|}
\hline Investment Style & Excess return & $\begin{array}{l}\text { Security Selection } \\
\text { Component }\end{array}$ & $\begin{array}{l}\text { Factor Timing } \\
\text { Component }\end{array}$ & $\begin{array}{l}\text { Risk Premium } \\
\text { Component }\end{array}$ \\
\hline $\begin{array}{l}\text { Illiquid-Style Hedge } \\
\text { Funds }\end{array}$ & $\begin{array}{c}0.42 \\
(100 \%)\end{array}$ & $\begin{array}{c}0.52 \\
(25 \%)\end{array}$ & $\begin{array}{l}-0.07 \\
(-16 \%)\end{array}$ & $\begin{array}{l}-0.04 \\
(-9 \%)\end{array}$ \\
\hline Convertible Arbitrage & $\begin{array}{c}0.17 \\
(100 \%)\end{array}$ & $\begin{array}{c}0.37 \\
(216 \%)\end{array}$ & $\begin{array}{c}-0.23 \\
(-137 \%)\end{array}$ & $\begin{array}{c}0.04 \\
(21 \%)\end{array}$ \\
\hline Emerging Markets & $\begin{array}{c}0.55 \\
(100 \%)\end{array}$ & $\begin{array}{c}0.75 \\
(137 \%)\end{array}$ & $\begin{array}{c}-0.10 \\
(-18 \%)\end{array}$ & $\begin{array}{c}-0.10 \\
(-19 \%)\end{array}$ \\
\hline Event Driven & $\begin{array}{c}0.51 \\
(100 \%)\end{array}$ & $\begin{array}{l}0.51 \\
(99 \%)\end{array}$ & $\begin{array}{c}0.00 \\
(-1 \%)\end{array}$ & $\begin{array}{l}0.01 \\
(2 \%)\end{array}$ \\
\hline Fixed Income Arbitrage & $\begin{array}{c}0.31 \\
(100 \%) \\
\end{array}$ & $\begin{array}{c}0.33 \\
(106 \%) \\
\end{array}$ & $\begin{array}{l}0.02 \\
(7 \%) \\
\end{array}$ & $\begin{array}{c}-0.04 \\
(-13 \%) \\
\end{array}$ \\
\hline Liquid-Style Hedge Funds & $\begin{array}{c}0.64 \\
(100 \%)\end{array}$ & $\begin{array}{l}0.50 \\
(78 \%)\end{array}$ & $\begin{array}{r}0.11 \\
(18 \%)\end{array}$ & $\begin{array}{l}0.03 \\
(4 \%)\end{array}$ \\
\hline Dedicated Short Bias & $\begin{array}{c}0.03 \\
(100 \%)\end{array}$ & $\begin{array}{c}0.12 \\
(424 \%)\end{array}$ & $\begin{array}{r}0.18 \\
(627 \%)\end{array}$ & $\begin{array}{c}-0.28 \\
(-951 \%)\end{array}$ \\
\hline Equity Market Neutral & $\begin{array}{c}0.45 \\
(100 \%)\end{array}$ & $\begin{array}{l}0.36 \\
(80 \%)\end{array}$ & $\begin{array}{r}0.09 \\
(20 \%)\end{array}$ & $\begin{array}{l}0.00 \\
(0 \%)\end{array}$ \\
\hline Global Macro & $\begin{array}{c}0.43 \\
(100 \%)\end{array}$ & $\begin{array}{c}0.32 \\
(75 \%)\end{array}$ & $\begin{array}{r}0.10 \\
(24 \%)\end{array}$ & $\begin{array}{l}0.01 \\
(2 \%)\end{array}$ \\
\hline Long/Short Equity Hedge & $\begin{array}{c}0.77 \\
(100 \%)\end{array}$ & $\begin{array}{c}0.58 \\
(75 \%)\end{array}$ & $\begin{array}{r}0.14 \\
(19 \%)\end{array}$ & $\begin{array}{l}0.05 \\
(6 \%)\end{array}$ \\
\hline Multi-Strategy & $\begin{array}{c}0.47 \\
(100 \%)\end{array}$ & $\begin{array}{c}0.42 \\
(89 \%)\end{array}$ & $\begin{array}{l}0.04 \\
(9 \%)\end{array}$ & $\begin{array}{l}0.01 \\
(2 \%)\end{array}$ \\
\hline All Hedge Funds & $\begin{array}{c}0.56 \\
(100 \%) \\
\end{array}$ & $\begin{array}{c}0.51 \\
(90 \%) \\
\end{array}$ & $\begin{array}{l}0.05 \\
(9 \%) \\
\end{array}$ & $\begin{array}{l}0.00 \\
(1 \%)\end{array}$ \\
\hline CTAS & $\begin{array}{c}0.69 \\
(100 \%)\end{array}$ & $\begin{array}{c}0.54 \\
(78 \%)\end{array}$ & $\begin{array}{c}0.22 \\
(32 \%)\end{array}$ & $\begin{array}{l}-0.06 \\
(-9 \%)\end{array}$ \\
\hline Fund of Funds & $\begin{array}{c}0.22 \\
(100 \%)\end{array}$ & $\begin{array}{c}0.22 \\
(100 \%)\end{array}$ & $\begin{array}{l}0.02 \\
(8 \%)\end{array}$ & $\begin{array}{l}-0.02 \\
(-8 \%)\end{array}$ \\
\hline All Funds & $\begin{array}{c}0.49 \\
(100 \%)\end{array}$ & $\begin{array}{c}0.44 \\
(90 \%)\end{array}$ & $\begin{array}{c}0.06 \\
(11 \%)\end{array}$ & $\begin{array}{l}-0.01 \\
(-1 \%)\end{array}$ \\
\hline
\end{tabular}




\section{Table 8. Decomposition of Excess Return (Fund-Level Test)}

This table shows how much of the excess return generated by hedge funds, CTAs, and FoFs during 1994 - 2008 are from security selection, factor timing, and risk premium. The unit of return is percent per month, and the reported numbers are sample averages. $t$-statistics are given in square brackets. ***, **, and * denote statistical significance at the 1 percent, 5 percent, and 10 percent level, respectively. The percentages in parentheses show the percentages of excess return generated by security selection, factor timing, and risk premium. The total percentages are written inside parentheses in the excess return column. If the excess return is positive, the total percentage is $100 \%$. The total percentage is $-100 \%$ if the excess return is negative.

\begin{tabular}{|c|c|c|c|c|c|}
\hline Investment Style & $\begin{array}{c}\text { Number } \\
\text { of } \\
\text { Funds }\end{array}$ & Excess return & $\begin{array}{l}\text { Security Selection } \\
\text { Component }\end{array}$ & $\begin{array}{l}\text { Factor Timing } \\
\text { Component }\end{array}$ & $\begin{array}{l}\text { Risk Premium } \\
\text { Component }\end{array}$ \\
\hline $\begin{array}{l}\text { Illiquid-Style Hedge } \\
\text { Funds }\end{array}$ & 330 & $0.55(100 \%)$ & $\begin{array}{c}0.58(105 \%) \\
{[15.58]^{\star \star \star}}\end{array}$ & $\begin{array}{c}-0.03(-5 \%) \\
{[-2.19]^{\star \star}}\end{array}$ & $\begin{array}{c}0.00(0 \%) \\
{[0.04]}\end{array}$ \\
\hline Convertible Arbitrage & 52 & $0.31(100 \%)$ & $\begin{array}{c}0.42(135 \%) \\
{[6.28]^{\star \star \star}}\end{array}$ & $\begin{array}{c}-0.13(-41 \%) \\
{[-3.94]^{\star \star *}}\end{array}$ & $\begin{array}{c}0.02(+6 \%) \\
{[0.98]}\end{array}$ \\
\hline Emerging Markets & 105 & $0.81(100 \%)$ & $\begin{array}{c}0.88(108 \%) \\
{[9.67]^{\star \star \star}}\end{array}$ & $\begin{array}{c}-0.06(-7 \%) \\
{[-1.60]}\end{array}$ & $\begin{array}{c}-0.01(-1 \%) \\
{[-0.31]}\end{array}$ \\
\hline Event Driven & 130 & $0.51(100 \%)$ & $\begin{array}{r}0.51(100 \%) \\
{[15.56]^{\star \star \star}}\end{array}$ & $\begin{array}{c}0.00(0 \%) \\
{[-0.09]}\end{array}$ & $\begin{array}{c}0.00(0 \%) \\
{[0.21]}\end{array}$ \\
\hline Fixed Income Arbitrage & 43 & $0.29(100 \%)$ & $\begin{array}{r}0.26(90 \%) \\
{[2.92]^{\star \star \star}}\end{array}$ & $\begin{array}{c}0.04(13 \%) \\
\quad[1.61]\end{array}$ & $\begin{array}{c}-0.01(-3 \%) \\
{[-0.28]}\end{array}$ \\
\hline $\begin{array}{l}\text { Liquid-Style Hedge } \\
\text { Funds }\end{array}$ & 576 & $0.66(100 \%)$ & $\begin{array}{l}0.47(72 \%) \\
{[20.64]^{\star \star \star}}\end{array}$ & $\begin{array}{c}0.08(12 \%) \\
{[5.69]^{\star \star *}}\end{array}$ & $\begin{array}{l}0.10(16 \%) \\
{[10.20]^{\star \star \star}}\end{array}$ \\
\hline Dedicated Short Bias & 13 & $-0.08(-100 \%)$ & $\begin{array}{c}-0.36(-430 \%) \\
{[-2.28]^{\star \star}}\end{array}$ & $\begin{array}{c}0.39(467 \%) \\
{[4.38]^{\star \star \star}}\end{array}$ & $\begin{array}{c}-0.11(-136 \%) \\
{[-0.74]}\end{array}$ \\
\hline Equity Market Neutral & 49 & $0.43(100 \%)$ & $\begin{array}{c}0.30(70 \%) \\
{[3.43]^{\star \star \star}}\end{array}$ & $\begin{array}{l}0.10(22 \%) \\
{[1.86]^{*}}\end{array}$ & $\begin{array}{c}0.04(8 \%) \\
{[1.75]^{*}}\end{array}$ \\
\hline Global Macro & 43 & $0.67(100 \%)$ & $\begin{array}{r}0.44(66 \%) \\
{[5.36]^{\star \star \star}}\end{array}$ & $\begin{array}{c}0.11(17 \%) \\
{[2.15]^{\star \star}}\end{array}$ & $\begin{array}{c}0.11(17 \%) \\
{[3.48]^{\star \star \star}}\end{array}$ \\
\hline $\begin{array}{l}\text { Long/Short Equity } \\
\text { Hedge }\end{array}$ & 378 & $0.75(100 \%)$ & $\begin{array}{r}0.54(72 \%) \\
{[19.16]^{\star \star \star}}\end{array}$ & $\begin{array}{c}0.07(10 \%) \\
{[3.98]^{\star \star \star}}\end{array}$ & $\begin{array}{l}0.14(18 \%) \\
{[10.32]^{\star \star \star}}\end{array}$ \\
\hline Multi-Strategy & 93 & $0.49(100 \%)$ & $\begin{array}{r}0.40(82 \%) \\
{[11.22]^{\star \star \star}}\end{array}$ & $\begin{array}{c}0.05(10 \%) \\
{[1.94]^{*}}\end{array}$ & $\begin{array}{r}0.04(8 \%) \\
{[2.82]^{\star \star \star}}\end{array}$ \\
\hline All Hedge Funds & 906 & $0.62(100 \%)$ & $\begin{array}{r}0.51(83 \%) \\
{[25.63]^{\star \star \star}}\end{array}$ & $\begin{array}{c}0.04(6 \%) \\
{[3.63]^{\star \star \star}}\end{array}$ & $\begin{array}{c}0.07(11 \%) \\
{[8.56]^{\star \star *}}\end{array}$ \\
\hline CTAS & 123 & $0.82(100 \%)$ & $\begin{array}{r}0.67(82 \%) \\
{[4.36]^{\star \star \star}}\end{array}$ & $\begin{array}{c}0.18(22 \%) \\
{[4.39]^{\star \star \star}}\end{array}$ & $\begin{array}{c}-0.04(5 \%) \\
{[-0.71]}\end{array}$ \\
\hline Fund of Funds & 328 & $0.33(100 \%)$ & $\begin{array}{r}0.29(86 \%) \\
{[14.69]^{\star \star \star}}\end{array}$ & $\begin{array}{c}0.02(6 \%) \\
{[2.25]^{\star *}}\end{array}$ & $\begin{array}{r}0.03(8 \%) \\
{[3.03]^{\star \star \star}}\end{array}$ \\
\hline All Funds & 1357 & $0.57(100 \%)$ & $\begin{array}{r}0.47(83 \%) \\
{[23.46]^{\star \star \star}}\end{array}$ & $\begin{array}{r}0.05(8 \%) \\
{[5.59]^{\star \star \star}}\end{array}$ & $\begin{array}{r}0.05(8 \%) \\
{[6.28]^{\star \star *}}\end{array}$ \\
\hline
\end{tabular}




\section{Table 9. Decomposition of Excess Return on HFRX Indices}

This table shows the decomposition of excess return on HFRX indices during the 7-year period between Apr 1, 2003 and Mar 31, 2010. Reported numbers are annualized percentage returns based on the assumption that there are 252 trading days in a year. Numbers inside parentheses show the percentages of excess return generated by security selection, factor timing, and risk premium. The total percentages are written inside parentheses in the excess return column. If the excess return is positive, the total percentage is $100 \%$. The total percentage is $-100 \%$ if the excess return is negative.

\begin{tabular}{|c|c|c|c|c|c|}
\hline Index & Description & Excess return & $\begin{array}{l}\text { Security } \\
\text { Selection }\end{array}$ & $\begin{array}{l}\text { Factor } \\
\text { Timing } \\
\end{array}$ & $\begin{array}{c}\text { Risk } \\
\text { Premium } \\
\end{array}$ \\
\hline AR & $\begin{array}{l}\text { Absolute Return (Designed to be } \\
\text { representative of the overall composition } \\
\text { of the hedge fund universe) }\end{array}$ & $\begin{array}{c}-3.00 \\
(-100 \%)\end{array}$ & $\begin{array}{l}-1.90 \\
(-63 \%)\end{array}$ & $\begin{array}{l}-1.39 \\
(-46 \%)\end{array}$ & $\begin{array}{c}0.29 \\
(+10 \%)\end{array}$ \\
\hline $\mathrm{CA}$ & Convertible Arbitrage & $\begin{array}{c}-8.42 \\
(-100 \%)\end{array}$ & $\begin{array}{c}-5.19 \\
(-62 \%)\end{array}$ & $\begin{array}{l}-3.57 \\
(-42 \%)\end{array}$ & $\begin{array}{c}0.34 \\
(+4 \%)\end{array}$ \\
\hline DS & Distressed Securities & $\begin{array}{c}-2.22 \\
(-100 \%)\end{array}$ & $\begin{array}{c}-2.51 \\
(-113 \%)\end{array}$ & $\begin{array}{c}0.26 \\
(+12 \%)\end{array}$ & $\begin{array}{c}0.03 \\
(+1 \%)\end{array}$ \\
\hline ED & Event Driven & $\begin{array}{c}2.44 \\
(100 \%)\end{array}$ & $\begin{array}{c}1.25 \\
(51 \%)\end{array}$ & $\begin{array}{c}-0.99 \\
(-41 \%)\end{array}$ & $\begin{array}{c}2.18 \\
(89 \%)\end{array}$ \\
\hline $\mathrm{EH}$ & Equity Hedge & $\begin{array}{c}-0.21 \\
(-100 \%)\end{array}$ & $\begin{array}{c}-3.91 \\
(-1862 \%)\end{array}$ & $\begin{array}{c}0.06 \\
(+29 \%)\end{array}$ & $\begin{array}{c}3.64 \\
(+1733 \%)\end{array}$ \\
\hline EMN & Equity Market Neutral & $\begin{array}{c}-2.27 \\
(-100 \%)\end{array}$ & $\begin{array}{c}-4.29 \\
(-189 \%)\end{array}$ & $\begin{array}{c}1.73 \\
(+76 \%)\end{array}$ & $\begin{array}{c}0.29 \\
(+13 \%)\end{array}$ \\
\hline EW & Equal Weighted Strategies & $\begin{array}{c}-0.40 \\
(-100 \%)\end{array}$ & $\begin{array}{c}-1.30 \\
(-325 \%)\end{array}$ & $\begin{array}{c}-0.38 \\
(-95 \%)\end{array}$ & $\begin{array}{c}1.28 \\
(+320 \%)\end{array}$ \\
\hline GL & $\begin{array}{l}\text { Global (Designed to be representative } \\
\text { of the overall composition of the hedge } \\
\text { fund universe) }\end{array}$ & $\begin{array}{c}0.13 \\
(100 \%)\end{array}$ & $\begin{array}{c}-1.59 \\
(-1223 \%)\end{array}$ & $\begin{array}{c}-0.38 \\
(-292 \%)\end{array}$ & $\begin{array}{c}2.10 \\
(+1615 \%)\end{array}$ \\
\hline $\mathrm{M}$ & Macro & $\begin{array}{c}1.18 \\
(100 \%)\end{array}$ & $\begin{array}{c}-3.94 \\
(-334 \%)\end{array}$ & $\begin{array}{c}3.27 \\
(+277 \%)\end{array}$ & $\begin{array}{c}1.85 \\
(+157 \%)\end{array}$ \\
\hline MA & Merger Arbitrage & $\begin{array}{c}3.38 \\
(100 \%)\end{array}$ & $\begin{array}{c}3.90 \\
(115 \%)\end{array}$ & $\begin{array}{l}-1.48 \\
(-44 \%)\end{array}$ & $\begin{array}{c}0.96 \\
(+28 \%)\end{array}$ \\
\hline MD & Market Directional & $\begin{array}{c}0.60 \\
(100 \%)\end{array}$ & $\begin{array}{c}-1.84 \\
(-307 \%)\end{array}$ & $\begin{array}{c}0.10 \\
(17 \%)\end{array}$ & $\begin{array}{c}2.34 \\
(390 \%)\end{array}$ \\
\hline RVA & Relative Value Arbitrage & $\begin{array}{c}-0.48 \\
(-100 \%)\end{array}$ & $\begin{array}{c}2.17 \\
(+452 \%)\end{array}$ & $\begin{array}{c}-3.47 \\
(-723 \%)\end{array}$ & $\begin{array}{c}0.82 \\
(+171 \%)\end{array}$ \\
\hline
\end{tabular}


Figure 1. Time Varying Market Risk Premium and Hedge Fund Beta
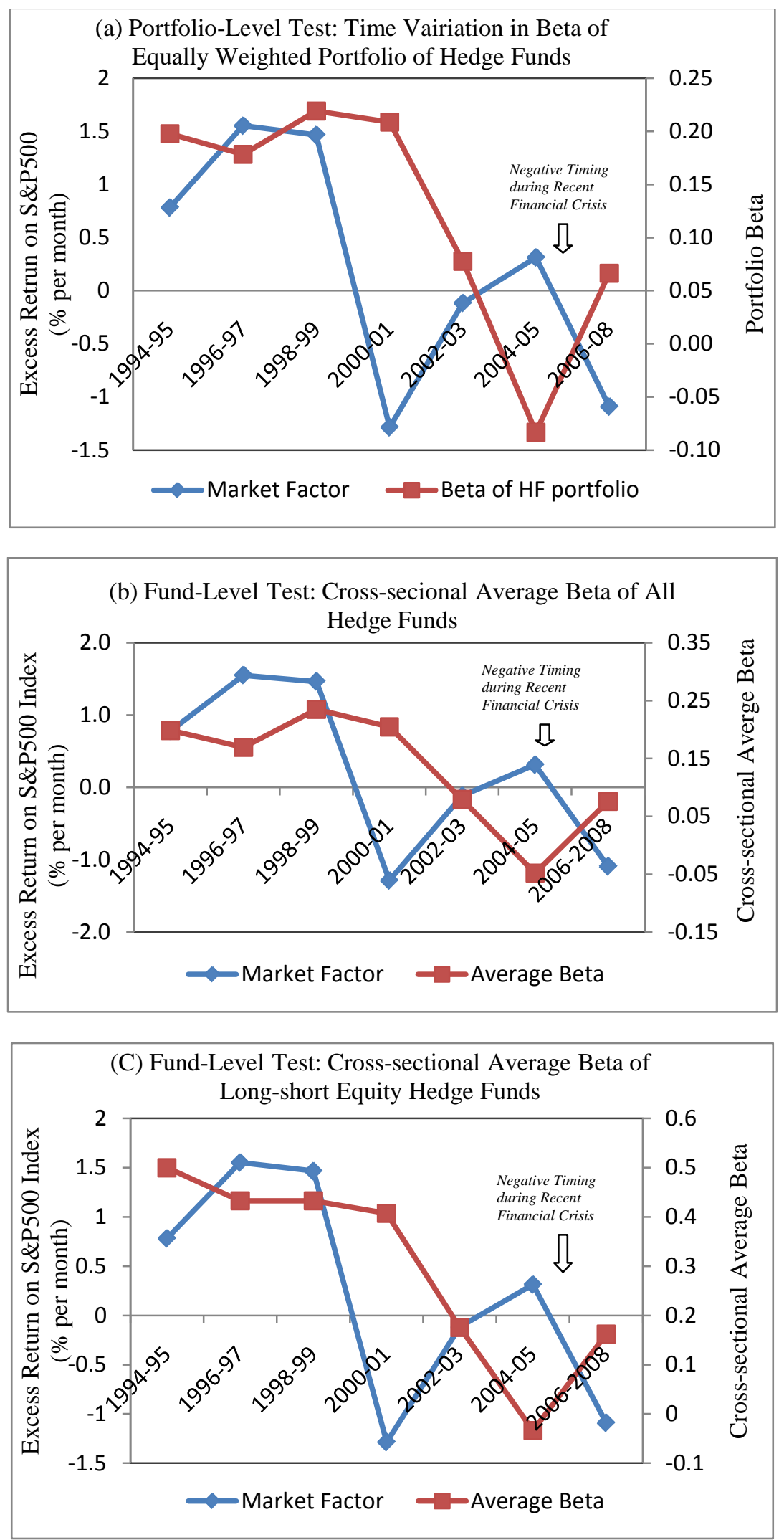
Figure 2. Time Varying Market Risk Premium and Daily Return on Hedge Fund Index

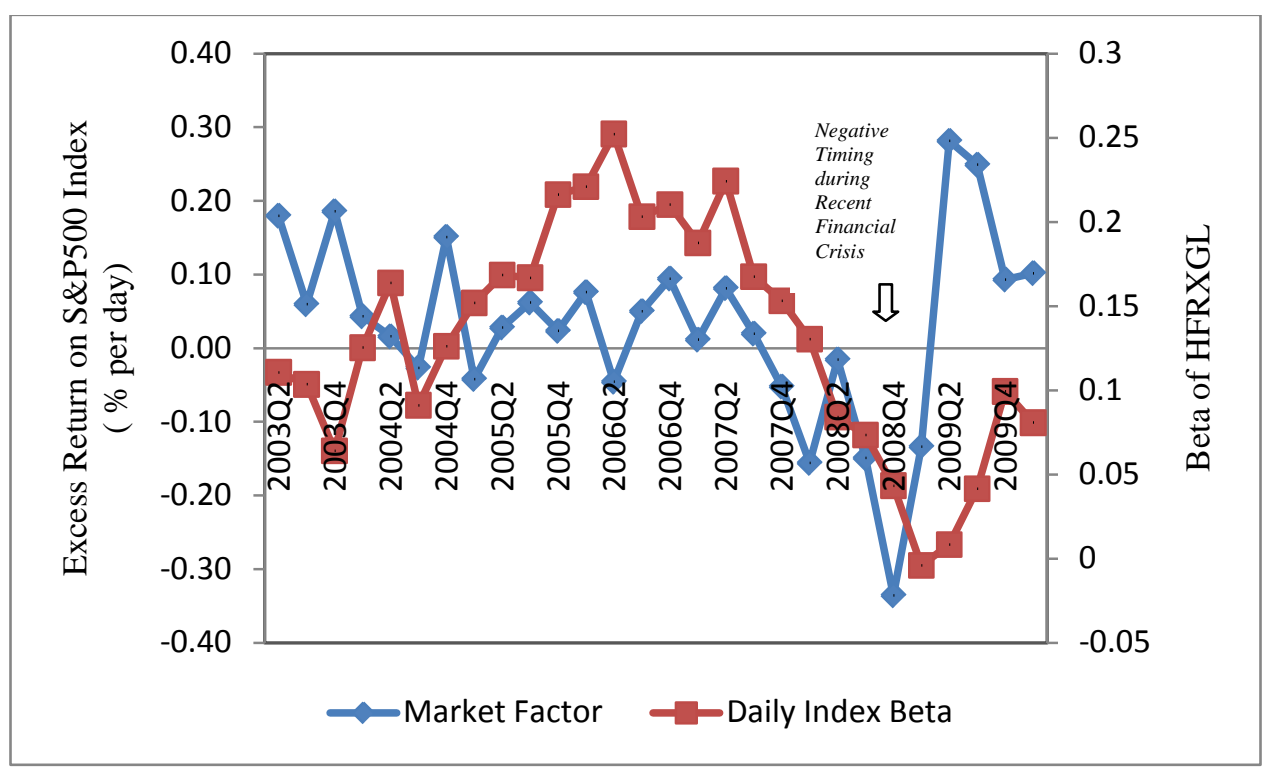

